University of Nebraska - Lincoln

DigitalCommons@University of Nebraska - Lincoln

$10-2020$

\title{
Asymmetric benefits of a heterospecific breeding association vary with habitat, conspecific abundance and breeding stage
}

\author{
Rose J. Swift \\ Michael J. Anteau \\ Erin A. Roche \\ Mark H. Sherfy \\ Dustin L. Toy
}

See next page for additional authors

Follow this and additional works at: https://digitalcommons.unl.edu/usgsnpwrc

Part of the Animal Sciences Commons, Behavior and Ethology Commons, Biodiversity Commons, Environmental Policy Commons, Recreation, Parks and Tourism Administration Commons, and the Terrestrial and Aquatic Ecology Commons

This Article is brought to you for free and open access by the US Geological Survey at DigitalCommons@University of Nebraska - Lincoln. It has been accepted for inclusion in USGS Northern Prairie Wildlife Research Center by an authorized administrator of DigitalCommons@University of Nebraska - Lincoln. 


\section{Authors}

Rose J. Swift, Michael J. Anteau, Erin A. Roche, Mark H. Sherfy, Dustin L. Toy, and Megan M. Ring 


\title{
OIKOS
}

\section{Research}

\section{Asymmetric benefits of a heterospecific breeding association vary with habitat, conspecific abundance and breeding stage}

\author{
Rose J. Swift, Michael J. Anteau, Erin A. Roche, Mark H. Sherfy, Dustin L. Toy and Megan M. Ring
}

R. J. Swift (https://orcid.org/0000-0001-7044-6196) ■ (rswift@usgs.gov), M. J. Anteau (https://orcid.org/0000-0002-5173-5870), E. A. Roche (https:// orcid.org/0000-0002-3823-2312), M. H. Sherfy (https://orcid.org/0000-0003-3016-4105), D. L. Toy (https://orcid.org/0000-0001-5390-5784) and M. M. Ring (https://orcid.org/0000-0001-8331-8492), U.S. Geological Survey, Northern Prairie Wildlife Research Center, 8711 37th Street SE, Jamestown, ND 58401, USA. Present address for EAR: Idaho Dept of Fish and Game, Boise, ID, USA.

\section{Oikos}

129: $1504-1520,2020$

doi: 10.1111/oik.07256

Subject Editor: Jiri Reif Editor-in-Chief: Dries Bonte Accepted 4 June 2020
Heterospecific breeding associations may benefit individuals by mitigating predation risk but may also create costs if they increase competition for resources or are more easily detectable by predators. Our understanding of the interactions among hetero- and conspecifics is often lacking in mixed species colonies. Here, we test how the presence of hetero- and conspecifics influence nest and chick survival for two listed (under the U.S. Endangered Species Act) migratory species breeding on the Missouri River, USA. We monitored 2507 piping plover Charadrius melodus nests and 3245 chicks as well as 1060 least tern Sternula antillarum nests and 1374 chicks on Lake Sakakawea, the Garrison River Reach and the Gavins Point Reach for varying years between 2007 and 2016. Piping plover nest and chick survival improved with the presence and abundance of least terns, but least terns only benefited from piping plover presence for certain study areas and breeding stages. Piping plover nest survival was also improved by the presence and abundance of conspecifics on the Garrison River Reach and was negatively influenced by conspecific presence on Lake Sakakawea. Least tern chick survival improved with the presence of other least terns only on the Gavins Point Reach. Ultimately, the heterospecific breeding association between plovers and terns is mutualistic but asymmetric and is moderated by habitat, abundance of conspecifics and breeding stage. Our results highlight that spatiotemporal variation in the interactions among individuals breeding in groups precludes simple generalizations and suggests that management focused on one species may restrict benefits to that focal species if nest site requirements for heterospecifics are not also included.

Keywords: antipredatory strategies, Charadrius melodus, chick survival, density dependence, heterospecific breeding aggregation, mixed species colony, mutualism, nest survival, Sternula antillarum

\section{Introduction}

Aggregations of individuals or species can incur costs as well as benefits from predation and competition that influence fitness (Lack 1968, Lima 2009, Mouton and Martin 2018). Heterospecific associations are generally considered to arise when

Published 2020. This article is a U.S. Government work and is in the public domain in the USA 
individuals benefit from group living because reduced niche overlap allows the benefits of larger group size to accrue without increasing conspecific competition (Alexander 1974, Krause and Ruxton 2002). Such benefits include a reduction of predation risk (Krause and Ruxton 2002, Harrison and Whitehouse 2011), increased efficiency in finding food (Aplin et al. 2012), enhanced ability to gather information on habitat quality (Seppänen et al. 2007) or increased foraging efficiency (Sridhar et al. 2009). In mixed species colonies, antipredator benefits may be derived not only from a group size effect but also from complementary characteristics of each species in the aggregation (Haemig 2001, Phelps et al. 2007) and may scale with population trends (Pöysä et al. 2019). Many of these benefits may also occur where conspecifics aggregate together, which may serve to maintain coloniality (Lack 1968, Campobello et al. 2011). However, densities of conspecifics may reach a threshold where competition inhibits coloniality (Farine et al. 2014a), while increasing densities of heterospecifics may provide additional benefits (Giroux et al. 2016). Therefore, the compositional balance within a heterospecific aggregation may influence the benefits of group living.

Within heterospecific associations, individuals interact with other species but also with conspecifics. Few studies have investigated the role of conspecific interactions in mixed species associations. Buskirk (1976) suggested that conspecific competition plays a primary role in the shift from monospecific to heterospecific groups, but only if predation risk is high. Farine et al. (2014a) showed that the distribution of species in mixed colonies can be realistically replicated using a simple decision rule: nest with conspecifics, but not too many. Importantly, this rule does not require a heterospecific attraction parameter, suggesting that individuals may be optimizing colony size as a tradeoff between attracting females and competing with conspecific males for mating opportunities. Further, any benefits and costs for nesting within a mixed species colony likely will be asymmetric (Groom 1992, Ellis and Good 2006), and different compositions of conand heterospecifics may influence antipredator behaviors and breeding success (Ellis and Good 2006, Sridhar et al. 2013, Sládeček et al. 2014). The nest density of the species using conspicuous and sometimes aggressive antipredator behavior could also shape patterns in predation risk for nearby nests. The direction of a density effect would depend on whether the increased nest density better repels (Andersson and Wiklund 1978) or attracts predators (Paulson and Erckmann 1985, Schmidt and Whelan 1999, Varela et al. 2007). Alternatively, the total group size or conspecific density may have a similar effect, thereby the total density of nesting neighbors may influence predation risk (Hamilton 1971, Pratte et al. 2016). Therefore, the costs and benefits of associating with conspecifics must also be examined when assessing the benefits of nesting among heterospecifics.

Heterospecific aggregations must benefit one or all individuals of the colony if selection is to act to maintain the interaction. Three hypotheses have been suggested to explain heterospecific breeding associations in birds: 1) an aggressive species defends its breeding area and, hence, the nests of other species in the area gain protection (protector species; Quinn and Ueta 2008), 2) mixed breeding colonies primarily function as an 'information centre' for food finding (Ward and Zahavi 1973) and, 3) birds can use the information contained in alarm calls and defense behaviors, thus avoiding predation (Nuechterlein 1981, Väänänen 2000). For instance, several studies showed that predation risk increases at increasing distances away from the nest of aggressive or territorial species such as the snowy owl Bubo scandiacus (Bêty et al. 2001) or from colonies of mobbing species such as mew gulls Larus canus (Swift et al. 2018). Alternatively, 'eavesdropping' on alarm calls can reduce the probability of detection by predators (Magrath et al. 2015). Descriptive studies of heterospecific nesting associations are relatively common (Quinn and Ueta 2008), but few studies have examined the mechanisms or the costs and benefits of the association to both species (but see Sládeček et al. 2014). In one example, terns and skimmers nesting with sand-colored nighthawks Chordeiles rupestris had reduced hatching success due to increased time spent in antipredator behaviors and less time in parental care (Groom 1992). Interactions within mixed species colonies range from parasitic (Groom 1992) to mutualistic (Campobello et al. 2011) to aggregations without clear costs or benefits to species (Mayer and Ryan 1991, Pratte et al. 2016). In this way, associations may occur due to mutual selection for similar habitat rather than a social choice.

Interactions among species may vary based on environmental conditions, availability of alternate prey sources or breeding stage. For instance, nesting near a species displaying a conspicuous and aggressive behavior like the Sabine's gull Xema sabini can decrease nest survival of red phalaropes Phalaropus fulicarius in years of high predation pressure when alternate prey populations are low (Smith et al. 2007). Even within a breeding season, predation pressure may vary based on the type and abundance of predators present (Alberico et al. 1991) or predator suites may change for eggs compared to precocial young (Swift et al. 2018). Precocial young in their first weeks after hatching are highly vulnerable to predation and may benefit from protection against predators within a protective association (Väänänen et al. 2016) or may interact with neighboring species differently (Swift et al. 2018). Predators may be more abundant or efficient in alternative habitats, increasing risk (Lecomte et al. 2008). Such variation in the function of heterospecific breeding associations suggests that such groupings may vary spatio-temporally or may be context dependent (Chamberlain et al. 2014). In short, the benefits of heterospecific associations may be nuanced and require studies that span entire breeding seasons across multiple years as well as holistically examine interactions.

On the Missouri River, USA, two federally listed (under the U.S. Endangered Species Act) species often nest in close proximity to one another, but the benefits and/or costs of these heterospecific nesting colonies is unknown. Piping 
plovers Charadrius melodus (threatened) and least terns Sternula antillarum (endangered but proposed for delisting) both nest on open, unvegetated sandbars and shorelines on river reaches and reservoirs on the Missouri River and least terns exhibit active defensive behaviors. Piping plovers, which exhibit passive nest defense, actively chose to nest near least terns on the Atlantic Coast, and plovers nesting within colonies of least terns were more successful than plovers nesting outside colonies (Burger 1987). However, on alkali wetlands in North Dakota, survival of artificial piping plover nests was not improved within American avocet Recurvirostra americana colonies compared to near solitary avocets (Mayer and Ryan 1991). However, it was unclear if the absence of a benefit to nest survival was due to small colonies of avocets, predator attraction to prey activity or that avocets were ineffective at driving predators away. Whether this heterospecific association creates any benefits for piping plovers or least terns is unknown on prairie rivers nor is the potential benefit of nesting near conspecifics.

In this study, we test the hypothesis that individuals may benefit from con- and heterospecifics nesting nearby in order to reduce predation risk during either the nesting or broodrearing stages. We use data on the presence of two migratory birds across three distinct study areas on the Missouri River to determine the effect of the presence of other breeding conspecifics and heterospecifics on nest and chick survival for both species. We located and followed nests and banded chicks of piping plovers and least terns to test if conspecific or heterospecific presence influenced nest and/or chick survival. We then examined how the abundance of both species at varying distances around a nest might influence nest survival. With this information, we can understand the potential costs and benefits for individuals nesting near conspecifics and/or heterospecifics throughout the entire breeding season as well as the species-specific conservation implications of these interactions.

\section{Material and methods}

\section{Study species}

Piping plovers (hereafter plovers) and least terns (hereafter terns) are migratory species that breed along sandbar and shoreline habitat of rivers and reservoirs in the U.S. Northern Great Plains. These breeding populations are both federally listed under the U.S. Endangered Species Act and habitat is managed extensively for both species along the Missouri River. Both species build nests on bare sand or cobble substrate. Piping plovers typically arrive earlier than least terns and begin nesting in May, while least terns arrive and begin nesting in mid-June. Piping plovers typically lay clutches of 4 eggs and least terns typically lay clutches of 2-3 eggs; the male and female of both species share incubation duties until hatching occurs (including egg-laying: approx. 35 days for piping plovers and 21 days for least terns). Piping plover chicks are precocial, mobile and capable of feeding themselves on the day they hatch. In contrast, least tern chicks are semiprecocial, dependent on their parents for food, and not fully mobile during the first few days following hatch. Both species depend on their parents for thermoregulation during the first week following hatch and remain with their parents until fledging (approx. 21 days for piping plovers and 16 days for least terns). Piping plovers generally exhibit passive defense against intruders. Generally, one or both plover adults use distraction displays, feign injury and/or try to lead predators away from nests and broods (Elliott-Smith and Haig 2004). Alternatively, least terns exhibit active defense against predators near nests and colonies though the response can vary with predator type. Adults may desert their nest/chicks if their own survival is at risk (e.g. from canids) but will call, dive, attack and mob against predators (Thompson et al. 1997). Defensive behaviors vary with the frequency of predator intrusions, colony size and nest age (Thompson et al. 1997).

\section{Study area}

Data on least tern and piping plover nests and chicks were collected on one reservoir and two riverine habitats in the U.S. Northern Great Plains (Fig. 1). Lake Sakakawea (SAK) is a mainstem reservoir of the Missouri River (from Garrison Dam near Riverdale, North Dakota to White Tail Bay, North Dakota; see Anteau et al. 2014a, b). The reservoir shoreline habitat was irregular, dissected and composed of a diversity of substrate types (Anteau et al. 2012a). Lake Sakakawea shoreline was divided into $5452-\mathrm{km}$ segments, 254 of which contained appropriate breeding habitat, of which 20-30 were randomly sampled annually for data collection prior to 2014 (2007, 2008, 2012-2013) and 40-67 segments were monitored in 2014-2016 (Table 1). The river habitat consisted of the Missouri River's Garrison River Reach (GRR) which extends from the Garrison Dam (river mile 1389) to the headwaters of Lake Oahe, $-10 \mathrm{~km}$ south of Bismarck, North Dakota (river mile 1277) and the Gavins Point Reach (GVP), which extends from the Gavins Point Dam (river mile 811) to Ponca State Park, Nebraska (river mile 754). Nesting habitat primarily consisted of mid-channel low- to midelevation sandbars with some established woody vegetation (Sherfy et al. 2008). During 2007, 2012-2013, 24-40 sandbars on GRR were randomly sampled (Shaffer et al. 2013; Table 1). From 2014 to 2016, 16 additional river miles, near the headwaters of Lake Oahe, were also surveyed for nesting birds in addition to the 86 river miles surveyed in previous years resulting in 44-56 sandbars monitored (Table 1). A random sample of available sandbars on GVP was monitored for nesting birds in 2008-2009 (Shaffer et al. 2013). For the purposes of this study, we refer to both a 2-km shoreline segment on SAK and a sandbar complex on GRR or GVP to be a 'site'. On GVP, to mitigate loss of suitable nesting habitat, the U.S. Army Corps of Engineers constructed sandbars from dredged or excavated sand ( 3 in autumn 2004 and 3 in autumn 2007) for the benefit of nesting terns and plovers (Catlin et al. 2011, Sherfy et al. 2012). Naturally occurring 


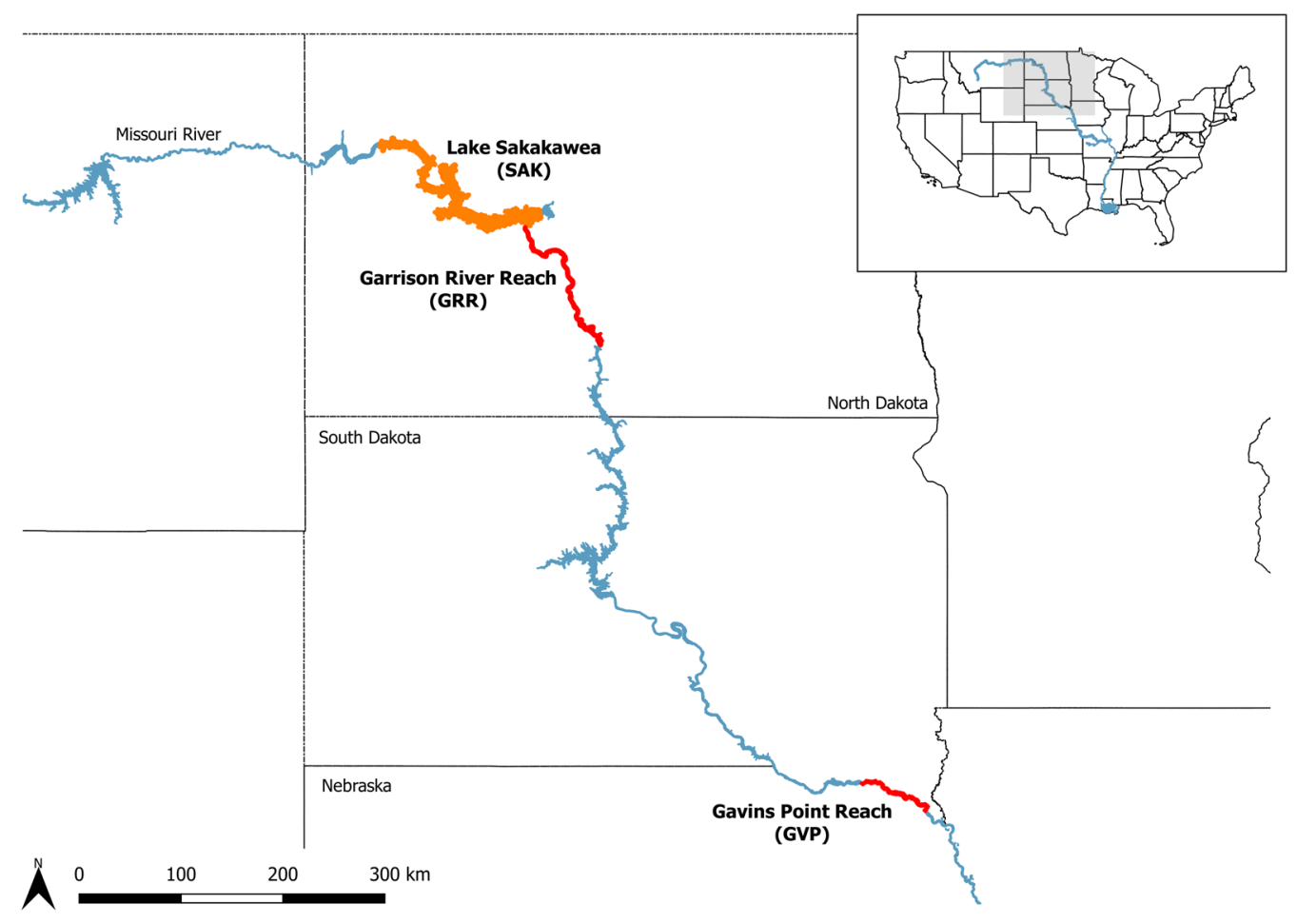

Figure 1. Map of the reservoir (orange) and riverine (red) habitats and Lake Sakakawea, Garrison River Reach, and Gavins Point Reach study areas on the upper Missouri River (blue).

Table 1. Sample of piping plover and least tern nests and uniquely marked chicks followed each year on riverine (Garrison River Reach of the Missouri River: 2007, 2012-2016 and Gavins Point Reach of the Missouri River: 2008-2009) and reservoir nesting habitat (Lake Sakakawea: 2007-2008, 2012-2016). Subscripts present the number of river sandbars (Garrison River Reach and Gavins Point Reach) or $2 \mathrm{~km}$ reservoir shoreline segments (Lake Sakakawea) over which the sample was distributed by species and year.

\begin{tabular}{lrrrrr}
\hline & \multicolumn{2}{c}{ Piping plover } & & \multicolumn{2}{c}{ Least tern } \\
\cline { 2 - 3 } \cline { 5 - 6 } Year & Nests & Chicks & & Nests & Chicks \\
\hline Garrison River Reach - & & & & & \\
2007 & $193_{35}$ & $352_{29}$ & & $99_{19}$ & $167_{18}$ \\
2012 & $56_{24}$ & $179_{28}$ & & $58_{12}$ & $131_{13}$ \\
2013 & $134_{40}$ & $247_{28}$ & & $68_{17}$ & $157_{16}$ \\
2014 & $275_{56}$ & $248_{30}$ & & $146_{32}$ & $155_{19}$ \\
2015 & $297_{53}$ & $233_{26}$ & & $146_{33}$ & $91_{19}$ \\
2016 & $286_{44}$ & $131_{22}$ & & $136_{19}$ & $86_{11}$ \\
Lake Sakakawea - & & & & & \\
2007 & $103_{22}$ & $99_{14}$ & & $9_{1}$ & $7_{1}$ \\
2008 & $92_{19}$ & $117_{13}$ & & $16_{3}$ & $15_{4}$ \\
2012 & $85_{17}$ & $244_{23}$ & & $8_{1}$ & $10_{1}$ \\
2013 & $117_{36}$ & $195_{28}$ & & $14_{6}$ & $17_{6}$ \\
2014 & $135_{40}$ & $114_{23}$ & & $13_{6}$ & $5_{3}$ \\
2015 & $152_{59}$ & $159_{42}$ & & $19_{8}$ & $12_{4}$ \\
2016 & $159_{67}$ & $219_{65}$ & & $20_{6}$ & $3_{2}$ \\
Gavins Point Reach - & & & & \\
2008 & $231_{30}$ & $396_{28}$ & & $181_{19}$ & $291_{15}$ \\
2009 & $192_{15}$ & $312_{13}$ & & $127_{9}$ & $227_{8}$ \\
\hline
\end{tabular}

sandbars created during the 1997 flood were also abundant during this study.

Both species are found in all three study areas, but at varying abundances. GVP contains the highest abundance of nesting least terns in the upper Missouri River system (Shaffer et al. 2013), and it also hosts a large nesting population of piping plovers. Least terns nest in low numbers at only a few sites on SAK and GRR hosts moderate numbers of both species. In addition, all three study areas have experienced significant water-level fluctuations during this study due to a combination of climate variability and water management. SAK experienced relatively low water levels in the early 2000 s prior to the historic 2011 flood (Anteau et al. 2019), which eliminated nearly all nesting habitat for the entire Missouri River system that year. Thus, habitat availability and therefore breeding bird abundance, varies each year.

\section{Field methods}

Crews of 2-3 researchers searched all available nesting habitat in the annual sample of reservoir and riverine sites. Nest searching for piping plover and least tern nests occurred approximately twice a week per site throughout the breeding season (May-July). Crews searched for nests using a combination of behavioral searching (in which crews observed adult behaviors to find nests) and grid searching (in which crews made grid-like-sweeps across expansive stretches of sandbar or shoreline habitat, Shaffer et al. 2013). Once a nest was found, researchers floated eggs to determine incubation 
stage and estimate the hatch date. Additionally, researchers recorded the number of eggs present, the identities of banded adults associated with the nest and the GPS location (see Shaffer et al. 2013 and Anteau et al. 2019 for more detailed discussion). Nests were revisited 2-3 times a week until termination; on the terminal visit, researchers collected evidence around the nest bowl and recorded the fate of the nest. Possible nest fates included: successful, probable successful, failed and unknown. Nests were classified as 'successful' only if at least one live chick was found in the nest bowl. 'Probable successful' nests lacked live chicks in the nest bowl and therefore required multiple other pieces of evidence of hatching (i.e. eggshells, pipping fragments, chick droppings or tracks). For the purpose of our analysis, probable successful nests and successful nests were both considered 'successful' (i.e. having hatched; see Shaffer et al. 2013 and Anteau et al. 2019 for more detailed discussion).

When possible, chicks of both species were banded in the nest bowl; if older and more mobile, chicks were banded following capture by hand or with butterfly nets. Researchers assigned chicks estimated ages based on plumage and skeletal development. Least tern chicks were banded with a USGS stainless steel metal band on the lower leg and 1) either a unique combination of three plastic color bands (20072009,2012 ) or 2) a yellow alphanumeric Darvic band on the lower leg opposite the metal band (2013-2016). Piping plover chicks on GRR and SAK were banded with a USGS aluminum metal band on the upper leg and either 1) a unique combination of four plastic color bands on the lower legs with a yellow plastic flag on the upper leg opposite the metal band $(2007-2008,2012)$ or 2) a single yellow alphanumeric Darvic flag on the upper leg opposite the metal band (2013-2016). Piping plovers on GVP were banded with a green plastic flag on the upper leg and a unique combination of 2-3 color bands (2008-2009). Sites with uniquely banded chicks were visited 2-3 times a week by researchers until chicks fledged (i.e. were capable of flight). Researchers used binoculars, spotting scopes, digital cameras and opportunistic recaptures to resight unique band combinations of chicks (see Roche et al. 2014 for more detailed discussion).

\section{Individual covariates}

We were interested in determining what effect the presence of breeding piping plovers and least terns had on the daily nest and chick survival of both species. For each nest and chick included in our analysis, we created occasion-specific individual covariates that represented if any piping plovers ( $\mathrm{pp}$ - 'plovers present') or least terns (tp - 'terns present') were present during the survival interval of interest (Table 2). To approximate heterospecific breeding presence, we used the following line of reasoning: we considered breeding individuals of species A to be 'present' if nests or chicks of species A were active at the same site and during the same time period as the nest or chicks of species B for which we were estimating survival. For example, when estimating least tern nest survival (i.e. species B) in relation to the presence of piping plovers (i.e. species A), for each least tern nest in our sample, we determined whether or not any piping plover nests or chicks were present at the same site and during the time the least tern nest was active.

Approximating conspecific breeding presence required an additional set of assumptions. Clearly, at least one breeding piping plover was already present at a site if we were estimating piping plover nest or chick survival at that site. Instead, we were interested in whether there were any additional breeding individuals. We again considered breeding individuals of species B to be 'present' if nests or chicks of species B were active at the same site and during the same time period as the nest or chicks of species B for which we were estimating survival. However, when using chicks to assume the presence of breeding individuals of species B, we assumed presence only if the number of chicks indicated more than one brood of species $\mathrm{B}$ was active at a site. The average brood size for least terns and piping plovers is 3 and 4 chicks, respectively. Thus, if more than 2 least tern chicks or 3 piping plover chicks were present at a site, we considered this evidence for the presence of other breeding adults of species B. Observations of 3 tern or 4 plover chicks occurred infrequently ( 4 and $11 \%$ of daily observations, respectively).

Whether or not least terns or piping plovers nested or raised chicks at a specific 'site' of interest was admittedly a crude description of species presence. For example, a $2 \mathrm{~km}$ stretch of reservoir shoreline or a large sandbar on the river could support nests and chicks of both species, but their placement could be sufficiently far apart that they would not be likely to interact. GPS locations of the mobile chicks were not routinely taken when resighting in all study areas and years, so when estimating chick survival in relation to species presence, presence at the 'site' level was the best information available. However, GPS locations were available for all nests monitored, allowing us to examine species presence at a level more reflective of the distance at which we would expect species to interact. To test this, we generated the number of active least tern and piping plover nests within varying distances of the focal nest $(5,10,50,100,200$ and $500 \mathrm{~m})$. For each nest included in our analysis, we created individual covariates that represented the number of active piping plover and least tern nests present within each radius of the nest during the period the nest was active. Each circle overlapped and included the number of nests active in the smaller circles. For example, when estimating least tern nest survival in relation to the number of piping plovers within $100 \mathrm{~m}$, for each least tern nest in our sample, we calculated the number of active piping plover nests within $100 \mathrm{~m}$ of the least tern nest at any point during the period in which the least tern nest of interest was active. In addition to providing us with a behaviorally significant measure of species presence, the individual buffer covariates allowed us to explore con- and heterospecific abundance effects at varying scales.

Lastly, for SAK and GVP, we included an additional variable that has been previously shown to affect nest survival. 
Table 2. Explanation of covariates and mean values (SD) used for nest survival analyses by species (PIPL $=$ piping plover, LETE $=$ least tern) and study area. Nesting habitat type (River=sandbars and shorelines along a river reach; Reservoir=shorelines of reservoirs or lakes). Sandbar type was only used on Gavins Point Reach, the only study area with constructed sandbars, and elevation over pool level was only used on the reservoir habitat (Lake Sakakawea).

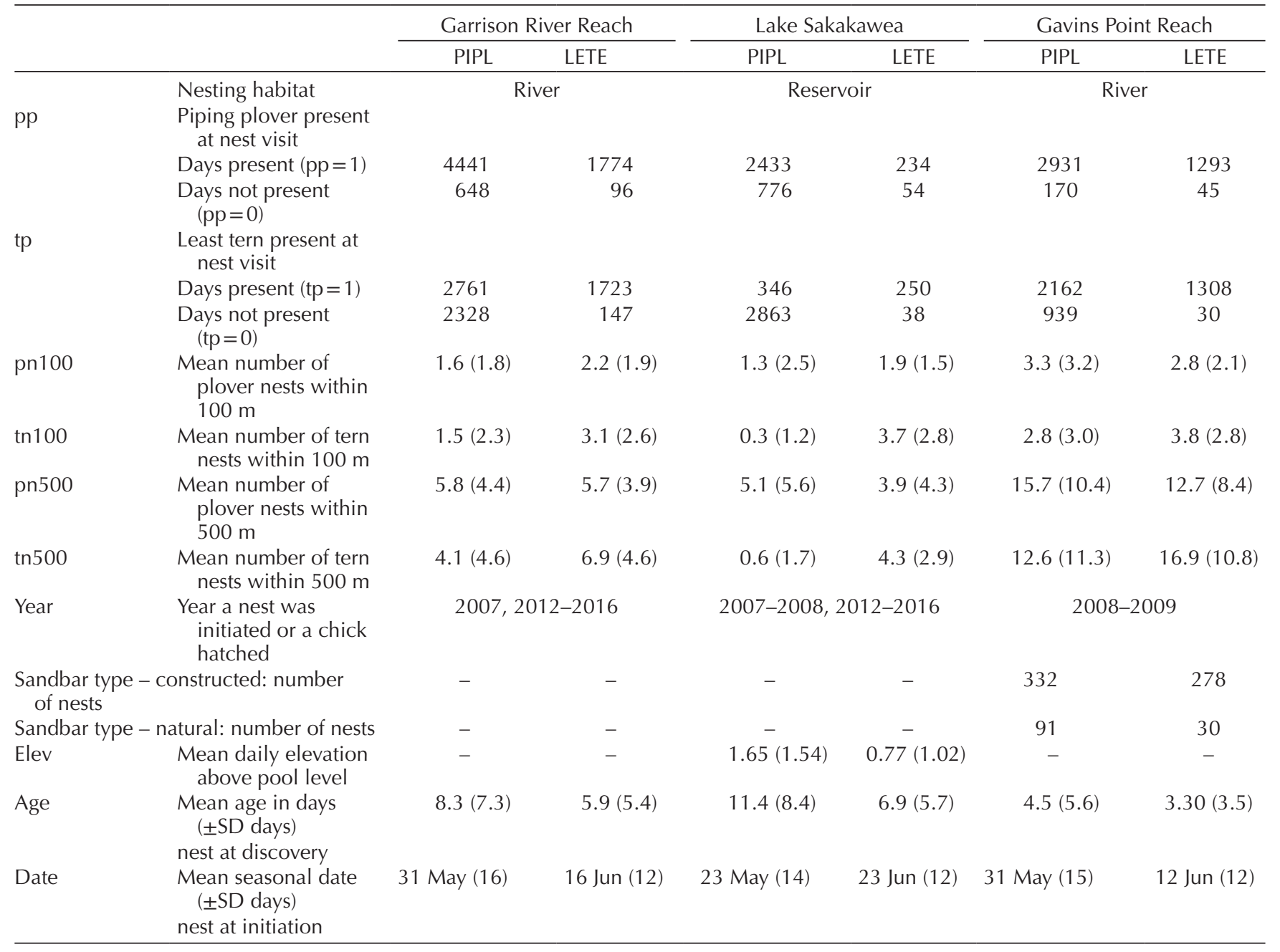

On GVP, we created a categorical variable that represented if the sandbar had been created naturally by high flows on the Missouri River in 1997 or constructed by the U.S. Army Corps of Engineers in the mid-2000s (Sherfy et al. 2008), as constructed sandbars have higher nest survival for piping plovers (Catlin et al. 2011) and nest success for least terns (Sherfy et al. 2012, Stucker et al. 2013). On SAK, we calculated an interval-specific relative elevation above the reservoir pool elevation (using a hyperbolic tangent transformation) because low-elevation nests are prone to inundation (Anteau et al. 2012b). From 2007 to 2014, we measured nest elevation using a 1) rotating laser level (LaserMark LMH-GR) relative to a nearby temporary elevation benchmark or 2) real-time kinematic survey. We measured benchmark elevations annually with survey-grade GPS equipment (Trimble GPS model 5800 and 5700) using fast-static data collection $>120$ min, National Geodetic Survey OPUS-static processing (National Oceanic and Atmospheric Administration, Washington, DC). When nest elevation was not measured in the field, it was derived from a digital elevation model for the GPS coordinates of the nest (all 2007-2008 least terns, all 2015-2016 nests for both species).

\section{Analysis}

We conducted all analyses separately for each study area and species because 1) we had adequate sample sizes within each study area to support independent analyses and 2) we believed a priori that differences in causes of reproductive failure or nesting abundance and distribution of breeding effort may have an effect on our results.

\section{Nest survival}

We built logistic-exposure models to estimate daily nest survival (Shaffer 2004) using program R (ver. 3.5.0, <www.rproject.org $>$ ). We calculated visit interval as the number of days between nest visits. The terminal visit date was either the known hatch date for the nest or the date the nest was 
known by our observers to have failed. We determined nest initiation dates (NID) using the visit date the nest was discovered (visit), the number of eggs at nest discovery (eggs), the incubation stage at nest discovery (stage) and the following formulas:

$$
\mathrm{NID}_{\text {PIPL }}=\text { visit }-((\text { eggs }-1) \times 2)-\text { stage }
$$

and

$$
\mathrm{NID}_{\text {LETE }}=\text { visit }-(\text { eggs }-1)-\text { stage }
$$

We then estimated hatch dates for least tern nests by adding 21 days to the estimated initiation date and for piping plover nests by adding 35 days to the estimated initiation date. When building models to estimate daily nest survival, we controlled for the effects of nest age (age), seasonal date (date) and year (Table 2).

We followed a step-wise model selection process for each unique combination of study area and species (i.e. a total of six separate nest survival analyses). The first step was to build and compete models accounting for additive and interactive effects of seasonal date and nest age. For SAK and GVP, we competed our additional covariates (relative elevation or sandbar type, respectively) in this first step. Using the topsupported model from this first step (i.e. model with the lowest AICc), we then added the year covariate and examined the interactive relationships date $\times$ year and age $\times$ year when applicable. After controlling for year, age, date, relative elevation and sandbar type where appropriate, the third model selection step involved adding our individual covariate representing the presence of least terns (tp) and piping plovers (pp), to the top supported model from the second model selection step. By adding the tp and pp covariates, we were able to estimate nest survival in relation to four scenarios: 1) breeding plovers and terns both present, 2) breeding plovers present but no terns present, 3) no breeding plovers present but terns present and 4) no breeding plovers or terns. We considered the top model from this third model selection step to be our best model of the effect of heterospecific presence on nest survival. If multiple models fell within seven AIC of the best supported model, we evaluated $85 \%$ confidence intervals $(\mathrm{CI})$ to determine if the addition of presence parameters was warranted (Arnold 2010, Burnham et al. 2011). Daily nest survival estimates were generated from our top-supported models with covariates set at their mean values (Table 2).

To investigate the effects of con- and heterospecific nest abundance on nest survival, we repeated the model selection process of our third step, but used our individual covariates accounting for the number of plover and tern nests within the varying distance buffers of the nest $(5,10,50,100,200$ and $500 \mathrm{~m}$ ) in place of the individual covariates measuring species presence at a site (i.e. covariates $\mathrm{pp}$ and $\mathrm{tp}$ ). We included both the number of plover and tern nests to account for con- and heterospecific effects concurrently. We tested each of these distances against each other and our presence model. We considered models that fell within seven AIC of the best supported model as competitive and evaluated $85 \%$ $\mathrm{CI}$ to determine our best model of the effect of abundance on nest survival (Arnold 2010, Burnham et al. 2011).

\section{Chick survival}

We built Cormack-Jolly-Seber models to estimate daily chick survival $(\varphi)$ and detection $(\mathrm{p})$ using program MARK (White and Burnham 1999) and the package 'RMark' (ver. 2.5.5; Laake 2013) in program R. We constructed 30-day age-structured capture histories for both least tern and piping plover chicks. When constructing capture histories, we used ' 1 ' to represent the detection of a chick at a specific site at a specific age. We distinguished between days a chick was not detected (' 0 ') and days a chick could not have been detected because the site at which it was located was not visited ('.'). Chick age was estimated at banding, and the first appearance of a chick in the capture history (i.e. the first ' 1 ') corresponded with the age it was estimated to be on the day of banding.

Because the availability of chicks to be resighted changes with the ability to fly (i.e. they may no longer be present at their hatch site during a visit), we parameterized all models for survival and detection accounting for this difference between prefledge and postfledge periods. We constructed two individual and occasion-specific dummy covariates (i.e. two separate intercepts): prefledge and postfledge. All least tern chicks received a ' 1 ' for prefledge from 1 to 16 days of age and a ' 0 ' for days 17-30, for postfledge the chicks received a ' 0 ' from 1 to 16 days of age and a ' 1 ' for days 17-30. All piping plover chicks received a ' 1 ' for prefledge from 1 to 21 days of age and a ' 0 ' for days 22-30, for postfledge the chicks received a ' 0 ' from 1 to 21 days of age and a ' 1 ' for days $22-30$. We were interested in estimating survival and the factors influencing survival during the period prior to fledging, so we automatically built interactions with prefledge when adding subsequent covariates to parameterize models of $\varphi$ and $p$. For each unique combination of study area and species (i.e. a total of six separate chick survival analyses), we estimated overdispersion using our most highly parameterized models of $\varphi$ and $p$ and the median c-hat test in program MARK.

Similar to our analysis of nest survival, we followed a stepwise model selection process. Because an understanding of the factors influencing chick detection was not our primary objective, our first step in this case was to determine our bestsupported model for detection probability (Lebreton et al. 1992). For each chick survival analysis, we parameterized our model of apparent survival as $\varphi$ (prefledge $\times$ year + prefledge $X$ year $X$ age + postfledge) and then competed the following parameterizations for detection probability: 1) prefledge + postfledge, 2) prefledge + prefledge $\times$ age + postfledge, 3) prefledge $\times$ year + prefledge $\times$ age + postfledge, 4) prefledge $\times$ year + prefledge $\times$ age $\times$ year + postfledge and 5 ) prefledge $\times$ year + postfledge. We considered the model with 
the parameterization of detection probability yielding the lowest QAICc (i.e. quasi-AICc or AICc corrected for small sample-size and overdispersion) the best-supported model of detection. We used this parameterization for detection probability when fitting and competing all subsequent models for apparent survival.

The second step was to build and compete model parameterizations for $\varphi$ accounting for additive and interactive effects of seasonal date and chick age. Using the top-supported model (i.e. lowest QAICc) from this second step, for our third step we then built and competed models accounting for annual differences in chick survival. Due to low sample sizes, we did not examine the interactive relationships date $\times$ year and age $\times$ year. After controlling for year, age and date where appropriate, the fourth model selection step involved adding both of our individual covariate representing the presence of least terns (tp) or piping plovers (pp). Because of limited sample sizes for some years and study areas, we additionally examined models with only tp and only pp. This meant we did not consider all four scenarios from the nest survival analysis in all cases due to data limitations. We considered the top model from this third model selection step to be our best model of heterospecific presence on chick survival. Again, if the addition of the presence variables did not improve model fit by seven AIC, we then evaluated $85 \%$ CI to determine our best model (Arnold 2010, Burnham et al. 2011). Daily survival estimates were generated from our topsupported models with covariates set at their mean values (Table 3) for the prefledging period.

We generated figures of cumulative nest survival to hatch and cumulative chick survival to fledge using daily survival estimates from our top-supported models. When present, daily survival estimates were generated with covariates set at their mean values (Table 1). To estimate cumulative survival to hatch, we assumed an incubation period of 21 days for least tern nests and an incubation period of 35 days for piping plover nests. We computed cumulative chick survival to fledging by taking the product of daily chick survival estimates out to 16 days for least tern chicks and out to 21 days for piping plover chicks. We used the delta method ('msm' package available in program R), daily survival rates generated at mean covariate values, and their associated variance-covariance matrices, to estimate cumulative survival rates and their associated $95 \%$ confidence envelopes. We used a log-odds transformation of the daily survival probability (Armstrong et al. 2002) to compute associated 95-percent confidence intervals to ensure estimates were bounded between 0 and 1 .

\section{Results}

\section{Piping plovers}

\section{Nest survival}

We estimated piping plover nest survival on GRR using a sample of 1241 piping plover nests that were distributed over
24-56 sandbar sites during 2007 and 2012-2016 (Table 1). On SAK, our sample of piping plover nests numbered 843 , and was annually distributed over 25-67 $2 \mathrm{~km}$ shoreline sites during 2007-2008 and 2012-2016 (Table 1). On GVP, we analyzed 423 nests on 15-30 sandbar sites during 2008-2009 (Table 1). While samples were annually variable, least terns were present at $40-59 \%$ of piping plover nest sites on the river reaches (GRR and GVP) and $2-27 \%$ of piping plover nest sites on the reservoir (Supplementary material Appendix 1 Fig. A1). Other piping plovers were present at $67-94 \%$ of piping plover nest sites on the river reaches and $55-82 \%$ of nest sites on the reservoir (Supplementary material Appendix 1 Fig. A1). The mean number of least tern nests within $500 \mathrm{~m}$ of a piping plover nest was higher on the river reaches than on the reservoir (Table 2, Supplementary material Appendix 1 Fig. A2).

Piping plover nest survival varied by date and nest age in all three study areas (Supplementary material Appendix 1 Table A1-A3). As the season progressed, the survival of piping plover nests decreased in all study areas but was annually variable on GRR and SAK (GRR: mean annual $\beta_{\text {date }}=-0.036 \pm 0.453 \mathrm{SD}$; SAK: mean annual $\beta_{\text {date }}=-0.142$ \pm 0.260 SD; GVP: mean annual $\beta_{\text {date }}=-0.132 \pm 0.121$ $\mathrm{SD})$. Although the effect of nest age on nest survival was annually variable, nest survival generally increased with nest age (GRR: mean annual $\beta_{\text {age }}=0.431 \pm 0.597$ SD; SAK: mean annual $\beta_{\text {age }}=0.181 \pm 0.289$ SD; GVP: mean annual $\left.\beta_{\text {age }}=0.409 \pm 0.106 \mathrm{SD}\right)$. On SAK, the effect of relative elevation of the nest varied annually but generally nests that were farther from the reservoir pool elevation had higher nest survival (mean annual $\beta_{\text {elevation }}=0.910 \pm 1.994$ SD), and on GVP, constructed sandbars had improved nest survival $\left(\beta_{\text {sandbar type }}=4.033 \pm 0.010 \mathrm{SE}\right)$ compared to natural sandbars $\left(\beta_{\text {sandbar type }}=3.730 \pm 0.167 \mathrm{SE}\right)$. In all three study areas, piping plover nest survival was positively associated with the presence of least terns (Fig. 2, Table 4, Supplementary material Appendix 1 Fig. A3). Daily and cumulative nest survival was lowest in all three study areas when only plovers were present (Fig. 2, Table 4, Supplementary material Appendix 1 Fig. A3). On GRR and SAK, nests that had neither plovers nor terns present had the highest daily and cumulative nest survival (Fig. 2, Table 4, Supplementary material Appendix 1 Fig. A3). On the river reaches and the reservoir, the odds of a piping plover nest surviving were 2.3 (GRR), 3.6 (GVP) and 1.3 (SAK) times higher on days during which breeding least terns were present (Fig. 2, Supplementary material Appendix 1 Fig. A3).

On both GRR and GVP, the number of both least tern and piping plover nests within $500 \mathrm{~m}$ of a piping plover nest was better than the simple presence of breeding least terns or other plovers on the site level at explaining daily nest survival (Supplementary material Appendix 1 Table A4-A6). Piping plover nest survival on GRR was positively associated with the number of least tern nests $\left(\beta_{\mathrm{tn} 500}=0.145 \pm 0.019\right.$ SE, Fig. 3a) and other piping plover nests within $500 \mathrm{~m}$ $\left(\beta_{\mathrm{pn} 500}=0.045 \pm 0.014\right.$ SE, Fig. 3a). Piping plover nest 
Table 3. Explanation of covariates and mean values (SD) used for chick survival analyses by species (PIPL $=$ piping plover, LETE $=$ least tern) and study area.

\begin{tabular}{|c|c|c|c|c|c|c|c|}
\hline & & \multicolumn{2}{|c|}{ Garrison River Reach } & \multicolumn{2}{|c|}{ Lake Sakakawea } & \multicolumn{2}{|c|}{ Gavins Point Reach } \\
\hline & & PIPL & LETE & PIPL & LETE & PIPL & LETE \\
\hline \multirow[t]{2}{*}{$\overline{\mathrm{pp}}$} & $\begin{array}{l}\text { Piping plover present } \\
\text { at site visit }\end{array}$ & & & & & & \\
\hline & Days not present $(p p=0)$ & 123 & 806 & 236 & 113 & 32 & 248 \\
\hline tp & $\begin{array}{l}\text { Least tern present at } \\
\text { site visit }\end{array}$ & & & & & & \\
\hline Year & Year a chick hatched & 2007,2 & -2016 & 2007-2008, & -2016 & 2008 & \\
\hline \multirow[t]{2}{*}{ Age } & $\begin{array}{l}\text { Mean age in days } \\
( \pm \text { SD days })\end{array}$ & & & & & & \\
\hline & Chick age at banding & $3.9(4.7)$ & $3.5(4.2)$ & $5.8(5.7)$ & $2.4(3.1)$ & $1.9(2.4)$ & $1.8(2.0)$ \\
\hline Date & $\begin{array}{l}\text { Mean seasonal date } \\
\quad( \pm \text { SD days })\end{array}$ & & & & & & \\
\hline
\end{tabular}

survival on GVP was positively associated with the number of least tern nests within $500 \mathrm{~m}\left(\beta_{\mathrm{tn} 500}=0.123 \pm 0.016 \mathrm{SE}\right.$, Fig. 3b) but was not associated with the number of piping plover nests $\left(\beta_{\mathrm{pn} 500}=-0.001 \pm 0.001 \mathrm{SE}\right.$, Fig. 3b).

\section{Chick survival}

During 2007 and 2012-2016, we uniquely banded 1390 piping plover chicks on 22-30 sandbar sites on GRR to estimate chick survival. On SAK, we uniquely banded 1147 piping
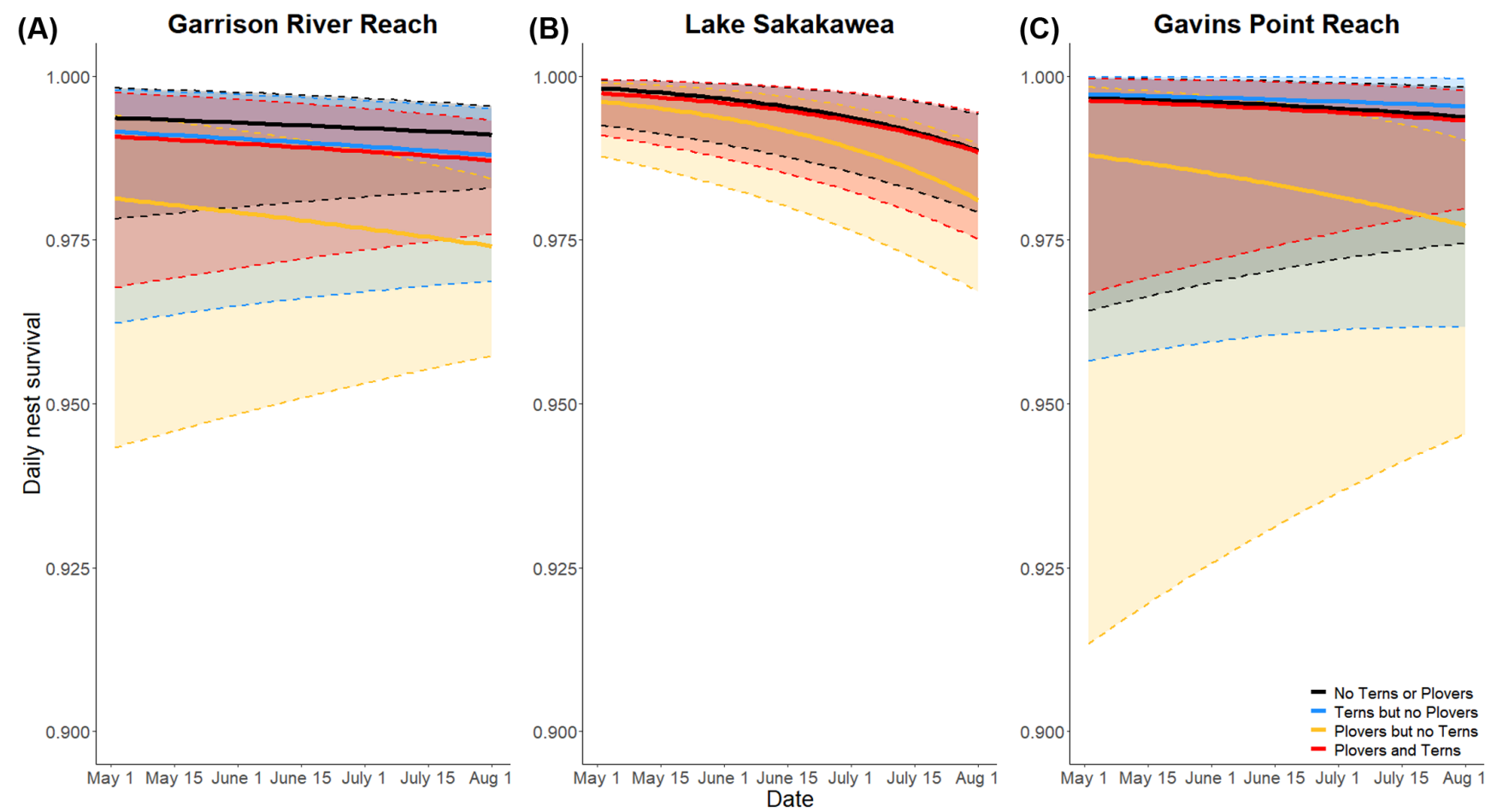

Figure 2. Daily nest survival to hatching (35 days) of piping plover nests on (A) the Garrison River Reach, (B) Lake Sakakawea, and (C) Gavins Point Reach relative to the presence of other piping plovers and least terns during the nesting period by date. Shaded polygons represent 95\% confidence envelopes for the predicted daily apparent survival values for nest survival when terns and plovers were both present (red), when only other plovers were present (yellow), only terns were present (blue) and when no terns nor other plovers were present (black). Daily nest survival estimates were generated using the top-supported model with covariates set to their mean values (A) $[S($ pp:tp + age $\times$ year + date $\times$ year $)],(B)[S(p p: t p+$ age $\times$ year + date $\times$ year + elevation $\times$ year $)]$, and $(C)[S(p p: t p+$ age $\times$ year + date $\times$ year + sandbartype $\times$ year $)$. 
Table 4. Mean cumulative nest survival and 95\% confidence intervals $(\mathrm{Cl})$ for each species (PIPL $=$ piping plover, LETE $=$ least tern) and study area for the four con- and heterospecific scenarios.

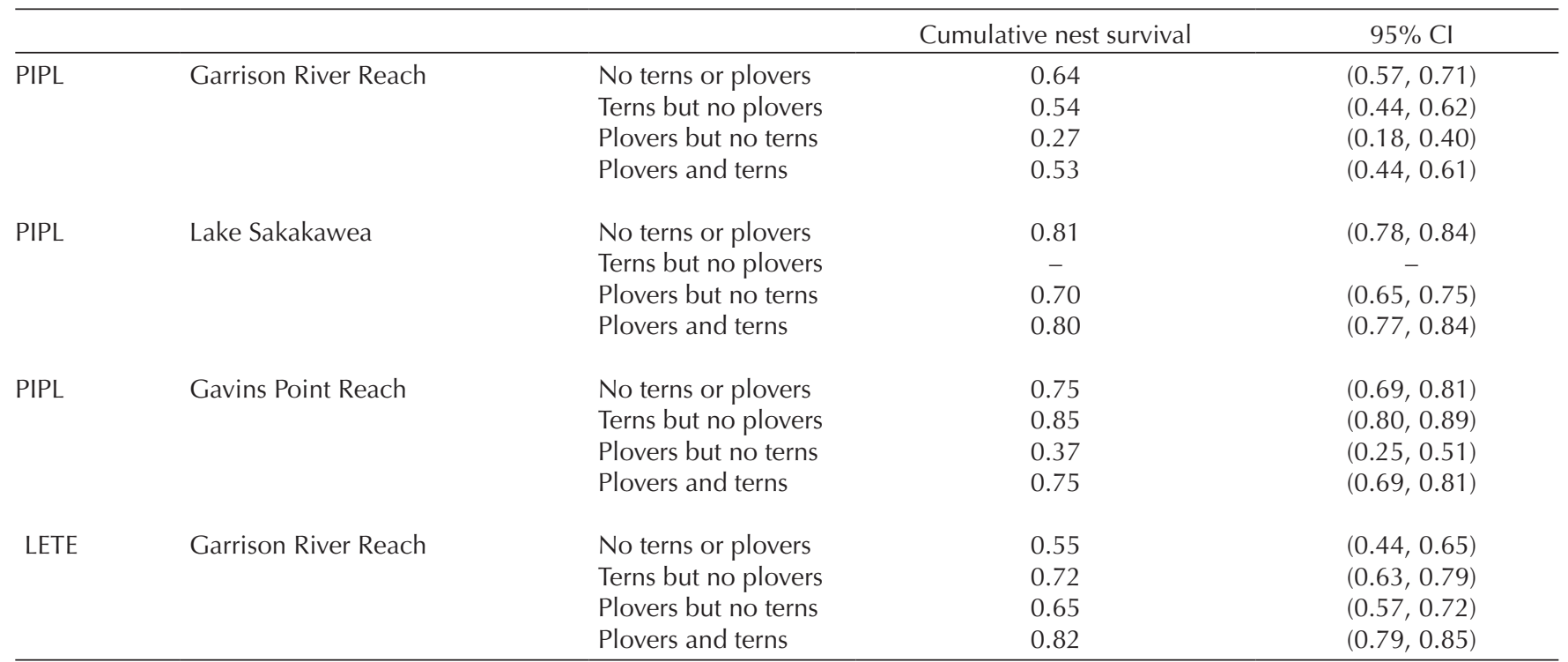

No significant effects of con- or heterospecifics for LETE on Lake Sakakawea or Gavins Point Reach.

plover chicks on 18-65 $2 \mathrm{~km}$ shoreline sites during 20072008 and 2012-2016. On GVP in 2008-2009, we uniquely banded 708 piping plover chicks on 13-28 sandbar sites (Table 1). As with our sample of nests, on the river reaches, more piping plover chicks were banded at sites where least terns were present, while on the reservoir more piping plover chicks were banded at sites where least terns were not present (Table 3). Breeding least terns were present at $53-95 \%$ of all piping plover chick hatch sites on the river reaches, while on the reservoir, breeding least terns were present at 2-28\% of all piping plover chicks hatch sites (Supplementary material Appendix 1 Fig. A4). Other breeding piping plovers were present at nearly all $(85 \%)$ piping plover chick hatch sites on the river reaches and the reservoir (Supplementary material Appendix 1 Fig. A4).

Piping plover chick survival to fledging varied by year on both the river reaches and the reservoir (Supplementary material Appendix 1 Table A7-A9). On the river reaches, we found that piping plover chick survival was associated with chick age (GRR: mean annual $\beta_{\text {age }}=-0.420 \pm 0.747$ SD, Supplementary material Appendix 1 Table A7; GVP: mean annual $\beta_{\text {age }}=0.035 \pm 0.022 \mathrm{SD}$, Supplementary material Appendix 1 Table A9) and with date (GRR: mean annual $\beta_{\text {date }}=-0.020 \pm 0.044 S D$, Supplementary material Appendix 1 Table A7; GVP: mean annual $\beta_{\text {date }}=0.009 \pm 0.037$ SD, Supplementary material Appendix 1 Table A9). In contrast, we found the survival of piping plover chicks on the reservoir to be unrelated to date or chick age (Supplementary material Appendix 1 Table A8). Piping plover chick survival was positively associated with the presence of least terns on GRR and SAK, but only marginally on GVP (Table 5, Supplementary material Appendix 1 Table A7-A9). The presence of other piping plovers did not influence piping plover chick survival in any study area (Supplementary material Appendix 1 Table A7-A9). The odds of a piping plover chick surviving were 1.5 and 2.0 times higher on days when breeding least terns were present on their brood rearing areas at GRR and SAK, respectively, than on days when they were not (Fig. 4).

\section{Least terns}

\section{Nest survival}

We estimated nest survival for 653 least tern nests annually distributed over 12-33 sandbar sites on GRR during 2007 and 2012-2016. On SAK, our sample of least tern nests totaled 99 and was annually distributed over 1-8 $2 \mathrm{~km}$ shoreline sites during 2007-2008 and 2012-2016. On GVP in 2008-2009, we followed 308 least tern nests on 9-19 sandbars (Table 1). In all years, piping plovers were present at the sites of $88-99 \%$ of our sample of least tern nests on the river, and $45-100 \%$ on the reservoir (Supplementary material Appendix 1 Fig. A5). Other least terns were present at $84-97 \%$ of all least tern nest sites on the river and $73-100 \%$ of all nest sites on the reservoir (Supplementary material Appendix 1 Fig. A5). The mean number of piping plover and other least tern nests within $500 \mathrm{~m}$ of a least tern nest was highest for GVP (Table 2, Supplementary material Appendix 1 Fig. A2).

Daily survival rates of least tern nests on GRR varied annually and were negatively associated with nest age (mean annual $\beta_{\text {age }}=-0.195 \pm 0.714$ SD, Supplementary material Appendix 1 Table A10). On SAK and GVP, daily nest survival rates varied with nest age (SAK: $\beta_{\text {age }}=-0.911 \pm 0.287$ SE, Supplementary material Appendix 1 Table A11; GVP: $\beta_{\text {age }}=0.726 \pm 0.241 \mathrm{SE}$, Supplementary material Appendix 1 Table A12) and with date (SAK: $\beta_{\text {date }}=0.587 \pm 0.292$ SE, 

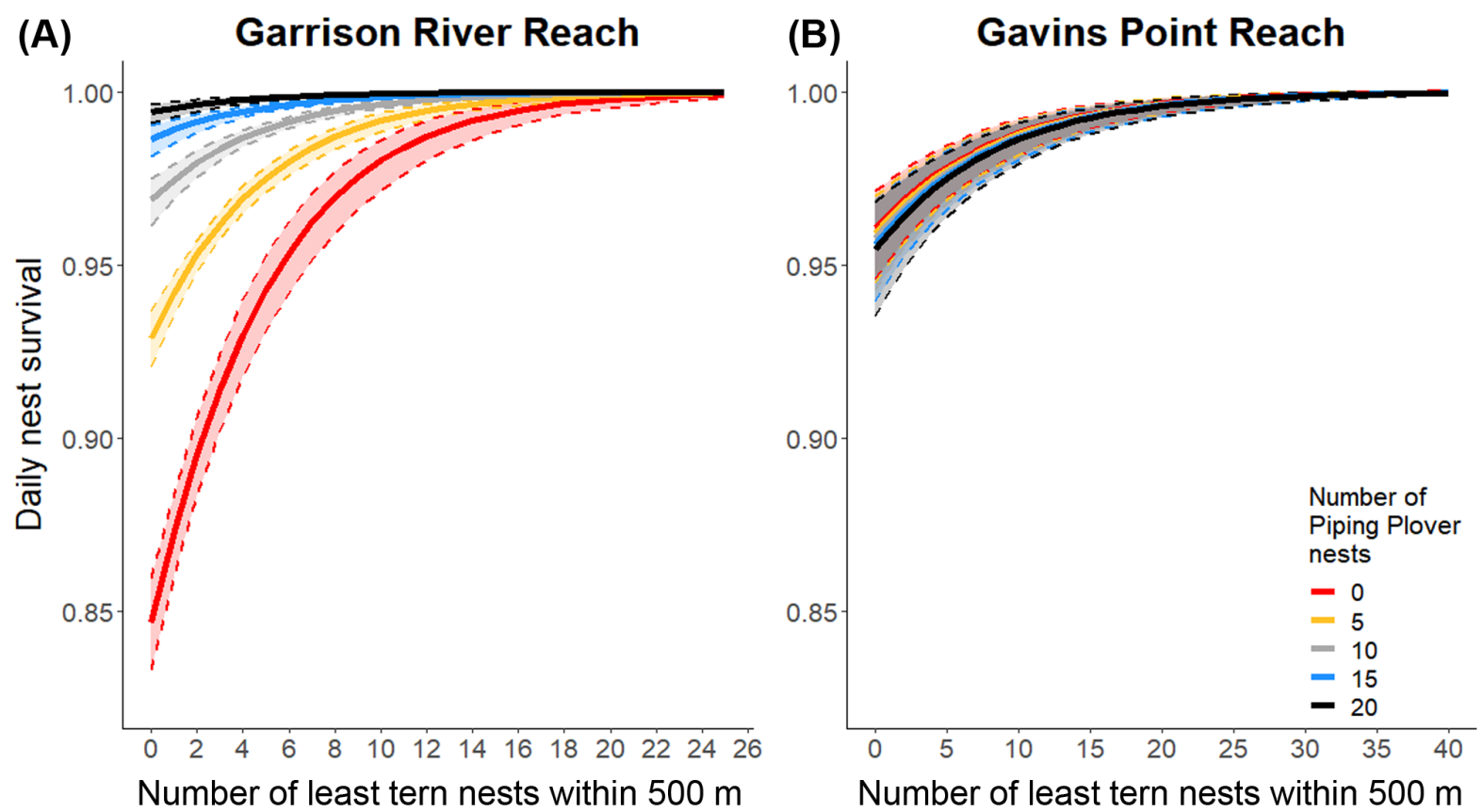

Figure 3. Daily nest survival for 10-day old piping plover nests on the (A) Garrison River Reach and (B) Gavins Point Reach relative to the number of other piping plover or least tern nests found within $500 \mathrm{~m}$ of the nest. Shaded polygons represent $95 \%$ confidence envelopes for the predicted daily apparent survival values. Daily nest survival estimates were generated using the top-supported model with covariates set to their mean values $(A)[S(\operatorname{tn} 500+$ pn $500+$ age $\times$ year + date $\times$ year $)]$ and $(B)[S(\operatorname{tn} 500+$ pn $500+$ age $\times$ year + date $\times$ year + sandbartype $\times$ year $)]$.

Supplementary material Appendix 1 Table A11; GVP: $\beta_{\text {date }}=-0.469 \pm 0.193$ SE, Supplementary material Appendix 1 Table A12).

Least tern nest survival was not associated with the presence of piping plovers at the site level on SAK or GVP (Supplementary material Appendix 1 Table A11-A12) but was positively associated with piping plover presence on GRR (Supplementary material Appendix 1 Table A10). Least tern nests on GRR that had neither species present at the site had the lowest daily and cumulative nest survival (Fig. 5, Table 4). The odds of a least tern nest surviving were 2.1 times higher on days when breeding piping plovers were present than on days when they were not on GRR (Fig. 5). Daily nest survival rates for least tern nests on GRR were positively associated $\left(\beta_{\text {pn 100 }}=0.165 \pm 0.076 \mathrm{SE}\right)$ with the number of piping plover nests within $100 \mathrm{~m}$ of the nest (Fig. 6, Supplementary material Appendix 1 Table A13), but we found no relationship with the number of other breeding least terns within $100 \mathrm{~m}$ $\left(\beta_{\text {tn100 }}=0.010 \pm 0.051 \mathrm{SE}\right)$.

\section{Chick survival}

During 2007 and 2012-2016, we uniquely banded 787 least tern chicks on 11-19 sandbar sites on GRR to estimate chick survival. On SAK, we uniquely banded 69 least tern chicks on 1-6 $2 \mathrm{~km}$ shoreline sites during 2007-2008 and 2012-2016. On GVP between 2008 and 2009, we uniquely banded 518 least tern chicks on 8-15 sandbars (Table 1). In nearly all cases, breeding piping plovers and least terns were present at the hatch sites of least tern chicks (Supplementary material Appendix 1 Fig. A6).

We found support for annual variation in daily survival rates for least tern chicks hatched on the river reaches but not for those hatched on the reservoir (Supplementary material Appendix 1 Table A14-A16). On GRR, the magnitude

Table 5. Mean cumulative chick survival to fledge and 95\% confidence intervals $(\mathrm{Cl})$ for each species $(\mathrm{PIPL}=\mathrm{piping}$ plover, $\mathrm{LETE}=\mathrm{least}$ tern) and study area.

\begin{tabular}{|c|c|c|c|c|}
\hline & & & Cumulative chick survival & $95 \% \mathrm{Cl}$ \\
\hline \multirow[t]{2}{*}{$\overline{\mathrm{PIPL}}$} & Garrison River Reach & Plovers but no terns & 0.30 & $(0.24,0.36)$ \\
\hline & & Plovers and terns & 0.46 & $(0.41,0.51)$ \\
\hline & & Plovers and terns & 0.46 & $(0.34,0.58)$ \\
\hline LETE & Gavins Point Reach & Terns but no plovers & 0.40 & $(0.22,0.61)$ \\
\hline
\end{tabular}

Only locations with significant con- and heterospecific parameters shown. 

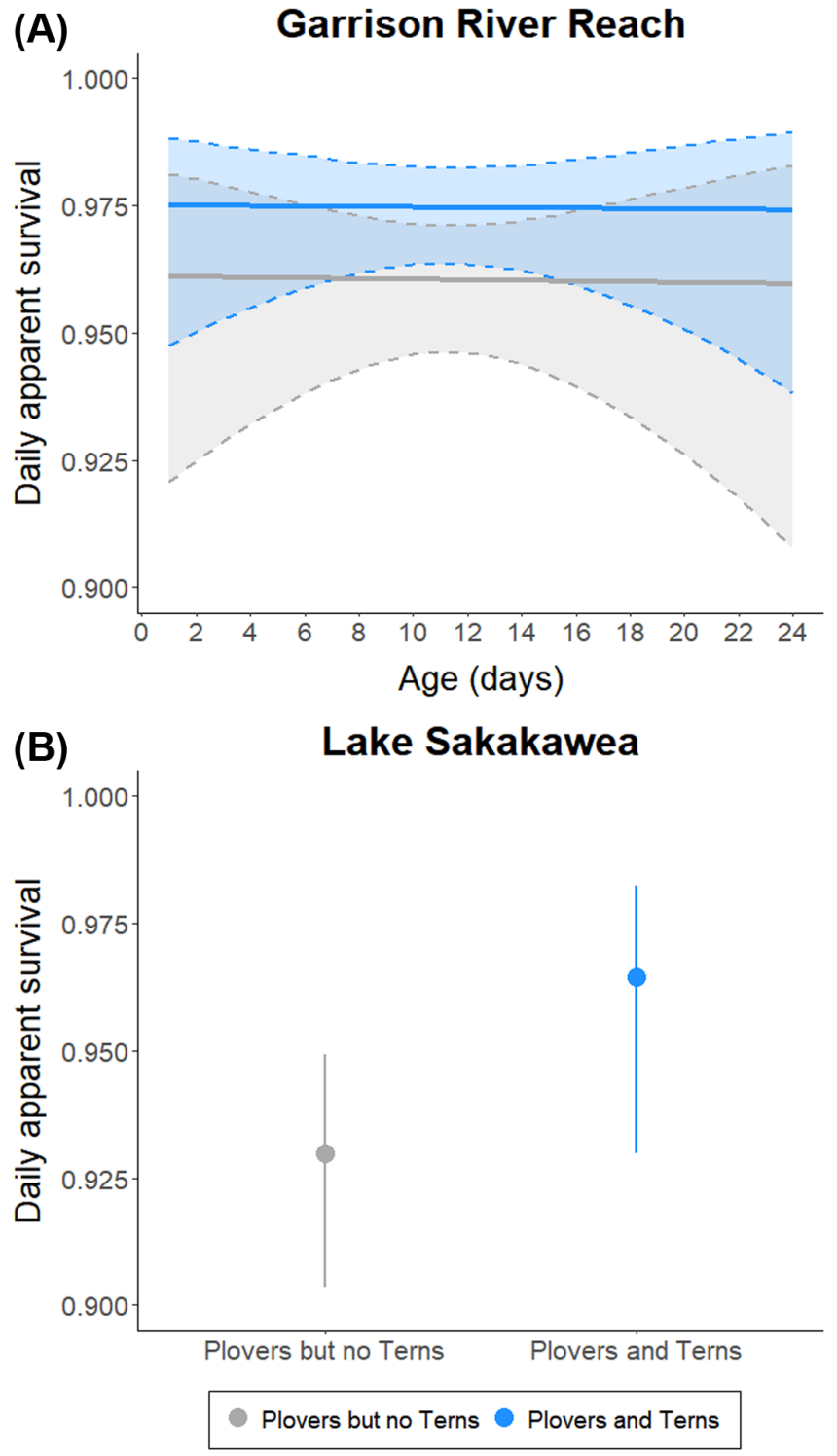

Figure 4. Daily survival to fledging age of piping plover chicks (21 days) hatched on the (A) Garrison River Reach and (B) Lake Sakakawea during 2013. Shaded polygons or lines represent $95 \%$ confidence envelopes for the predicted daily apparent survival values. Daily chick survival estimates were generated using the topsupported model with covariates set to their mean values (A) $[\varphi$ (tp:prefledge + age:year:prefledge + date:year:prefledge + year: prefledge+postfledge $), \quad$ p (prefledge:age $\times$ year + prefledge:year + postfledge)], and (B) [ $\varphi$ (tp:prefledge + year:prefledge + postfledge), $\mathrm{p}$ (prefledge:age+prefledge:year + postfledge) $]$.

and direction of the relationship between chick survival and date was annually variable. In general, least tern chick survival was positively associated with date (mean annual $\beta_{\text {date }}=0.030 \pm 0.106 \mathrm{SD}$, Supplementary material Appendix 1 Table A14). On the reservoir, least tern chick survival was negatively associated with chick age $\left(\beta_{\text {age }}=-0.094 \pm\right.$ 0.085 SE, Supplementary material Appendix 1 Table A15). On GVP, least tern chick survival was not associated with

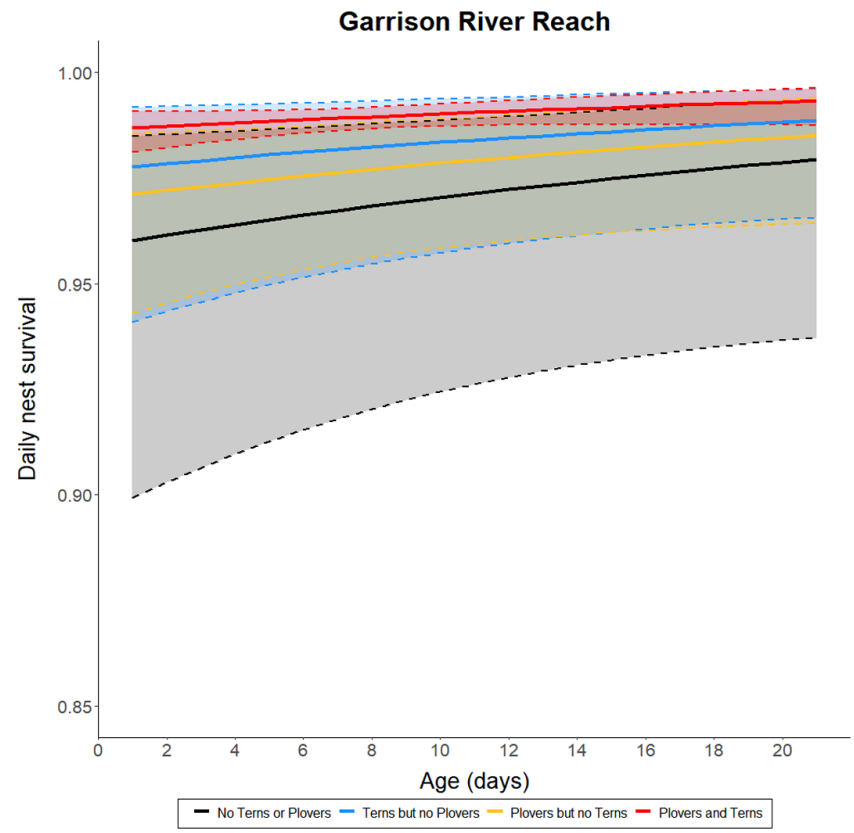

Figure 5. Daily nest survival to hatching (21 days) of least tern nests on the Garrison River Reach relative to the presence of piping plovers and other least terns during the nesting period. Shaded polygons represent $95 \%$ confidence envelopes for the predicted daily apparent survival values for nest survival when terns and plovers were both present (red), when only plovers were present (yellow), only other terns were present (blue) and when no other terns nor plovers were present (black). Daily nest survival estimates were generated using the top-supported model with covariates set to their mean values $[S(p p: t p+$ age $\times$ year $)]$.

either chick age or date but did vary annually (Table 5, Supplementary material Appendix 1 Table A16).

Least tern chick survival was only marginally associated with the presence of piping plovers and positively associated with other least terns on GRR (Supplementary material Appendix 1 Table A14). No relationship was found on SAK, where least tern colonies are small and infrequent (Supplementary material Appendix 1 Table A15). On GVP, least tern chick survival was positively associated with the presence of piping plovers and least terns (Table 5, Supplementary material Appendix 1 Table A16). The odds of a least tern chick surviving were 1.8 times higher on days when breeding piping plovers were present than on days when they were not on GVP (Fig. 7).

\section{Discussion}

The heterospecific breeding association between piping plovers and least terns on the Missouri River was mutualistic but asymmetric and was moderated by habitat and abundance of conspecifics. In addition, it varied among years and across breeding stages. Overall, piping plover nest and chick survival were improved by the presence of least terns. The interaction between species was asymmetric with plovers gaining a larger benefit from the association than terns. Least terns nesting 


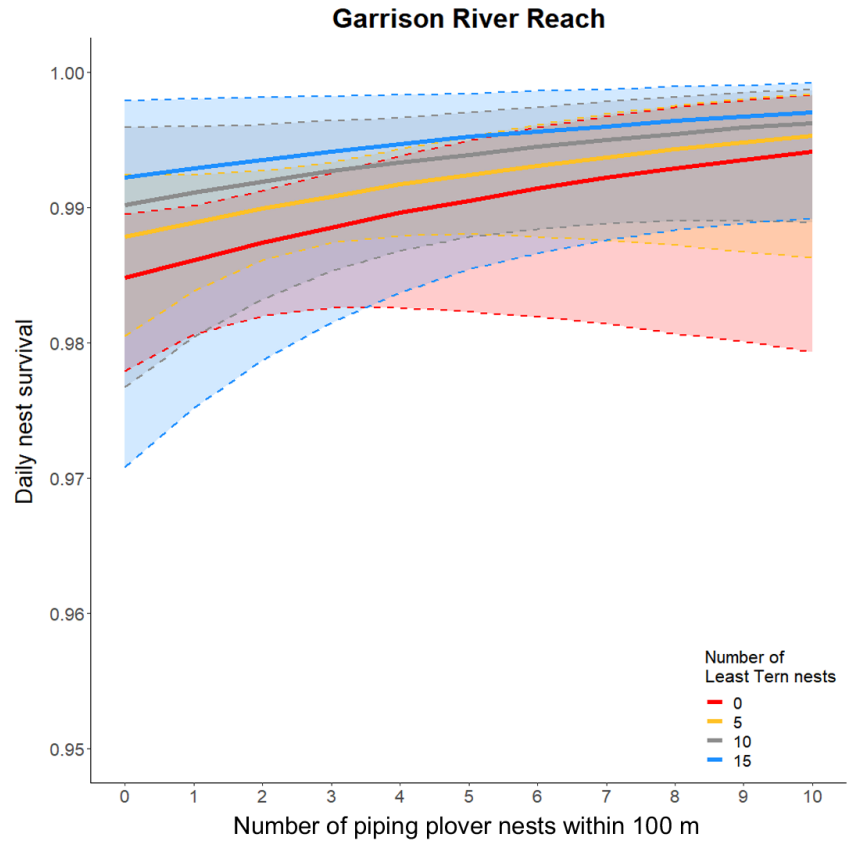

Figure 6. Daily nest survival for 10-day old least tern nests on the Garrison River Reach relative to the number of piping plover or other least tern nests found with a $100 \mathrm{~m}$ of the nest. Shaded polygons represent $95 \%$ confidence envelopes for the predicted daily apparent survival values. Daily nest survival estimates were generated using the top-supported model with covariates set to their mean values $[S(\operatorname{tn} 100+$ pn $100+$ age $\times$ year $)]$.

on river reaches also benefited from the presence of piping plovers and least terns in either the nest or brood-rearing stage depending on study area. Interestingly, the presence of conspecifics had mixed results for nesting piping plovers with the abundance of other breeding piping plovers only beneficial on GRR. While there was a general pattern of mutualism in this heterospecific breeding association, the nuanced response among breeding contexts suggests that other, nonconsidered, parameters may interact with these patterns.

Both piping plovers and least terns benefited from nesting in mixed species colonies. While this benefit varied, it was mutualistic in most contexts we evaluated; however, the mechanism driving the survival benefits is still unknown. One possibility is that plovers benefit from active protection from mutual predators by terns, which exhibit active defense contrary to plovers (Quinn and Ueta 2008). Terns can effectively discourage avian predators, which are common along the river reaches (Thompson et al. 1997). Alternatively, individuals may use the alarm calls of both con- and heterospecifics as an early warning system of approaching predators. Both species could use the colony to glean information on the presence of nearby predators to allow them to engage in defensive behaviors or behaviors that reduce detection of nests or chicks (Nuechterlein 1981, Doligez et al. 2002). One additional possibility is that individuals are benefiting from a group size effect - either through dilution or saturation (Hamilton 1971). Colonies below a certain density threshold
Gavins Point Reach

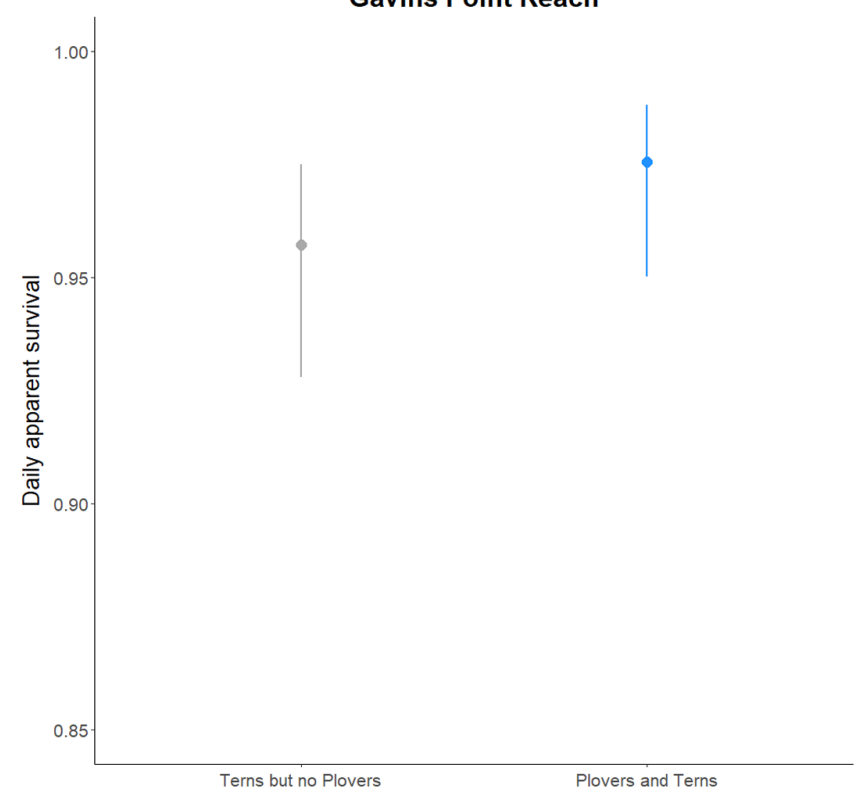

Figure 7. Daily survival to fledging age of least tern chicks (16 days) hatched on the Gavins Point Reach. Lines represent 95\% confidence envelopes for the predicted daily apparent survival values. Daily chick survival estimates were generated using the top-supported model with covariates set to their mean values $[\varphi(\mathrm{tp}$ :prefledge + year:prefledge + postfledge $), \quad \mathrm{p}$ (prefledge: age + prefledge:year + postfledge) $]$.

could attract predators, but not offer sufficient protection, and large colonies may attract more predators leading to an optimal middle colony size (Brunton 1999). This may be true for least terns, which had low daily nest survival when neither species was present and when nearby abundances were low; however, plover nests that were alone had high survival - suggesting that plovers may actually suffer some costs to aggregating. Thus, further study is needed to identify the mechanisms that drive the association between nesting plovers and terns on the Missouri River.

Contrary to expectations for a colonial, mobbing species, we found few benefits of nesting near conspecifics for least terns. For the two river reaches, the presence of other breeding least terns moderately improved nest and/or chick survival; however, there was no effect for the reservoir habitat during either breeding stage. Least terns nest on SAK in low numbers and in only a few areas. Likely, the abundance of nesting least terns on SAK is too low to be effective at dissuading predators - similar to on the Atlantic coast where small colonies fail (Brunton 1999). In general, however, variation in colony size of least terns appears unimportant on the Missouri River during incubation unless neither species is present (Brown et al. 1990). Terns nest in loose semi-colonial groups along prairie rivers rather than dense colonies seen on the Atlantic coast (Thompson et al. 1997). One possible mechanism for our results is that two adult least terns provide adequate protection of their own nest in generally loose aggregations, especially when nests are rarely unattended. 
In contrast, their semi-precocial chicks are mobile after a few days and may be spread apart with parents both absent foraging, so individuals may benefit to join in antipredator behaviors as young from multiple family groups may merge or the location of their brood is unknown. In this way, the stage of breeding may moderate the benefits of associating with other individuals as has been seen with ducks and shorebirds nesting near gulls (Väänänen et al. 2016, Swift et al. 2018). As such, the benefit for nesting in conspecific aggregations for least terns appear to be context-dependent and is most pronounced during the brood-rearing period.

The presence of other nesting piping plovers had mixed results on piping plover nest survival. On GRR, the presence and abundance of piping plover nests within $500 \mathrm{~m}$ improved daily nest survival; whereas, on GVP, it had no effect. On SAK, reduced nest survival when conspecifics were present may be the result of conspecific competition or due to differences in habitat that allowed for plovers to nest in closer proximity. Predator suites are likely different on reservoirs compared to river reaches, which appear to have more avian predators, though little is known about predator communities on reservoirs (Kruse 1993, Andes et al. 2019). When reservoir levels are low, habitat can be highly abundant which may reduce predation risk. Further, reservoirs often see a mid-summer water level rise which inundates nests (Anteau et al. 2012b), which rarely occurs on river reaches (Swift et al. 2020a). Overall, predation may not be as large of a risk for plovers nesting on reservoirs than river reaches. Competition for food or nesting sites would be elevated if the abundance or density of plovers was high (Mouton and Martin 2018). However, GRR had a similar count of conspecifics within $500 \mathrm{~m}$ as SAK but much lower than GVP (mean abundance of other piping plover nests; GRR: 5.79; SAK: 5.12; GVP: 15.7). In all three study areas, the mean number of other piping plover nests within $500 \mathrm{~m}$ is roughly twice as high when terns are present (GRR: no terns $=3.57$, terns present $=6.85$; SAK: no terns $=4.67$, terns present $=8.03$; GVP: no terns $=10.7$, terns present $=16.8$ ) although GRR has lower counts than SAK and GVP. One other possible mechanism that may result in conspecifics reducing nest success is conspecific aggressive behaviors in order to maintain territories (Groom 1992, Pius and Leberg 1997). Piping plovers nested closer together in mixed species colonies with 26 plover nests that had one active neighbor within $5 \mathrm{~m}$, nesting much closer than the average territorial spacing of over $14 \mathrm{~m}$ for the species (Elliott-Smith and Haig 2004). With nearer neighbors, individuals may spend more time in aggressive, territorial interactions within a heterospecific association; thereby, individuals may spend less time on parental care reducing hatching success (Groom 1992, Pius and Leberg 1997). Despite nesting in loose colonies throughout the species' range, the potential benefits of nesting near conspecific piping plovers are not clear cut and in fact may reduce nest survival in certain contexts.

Previous research on piping plovers nesting at high densities on the GVP study area has shown that density-dependent processes lead to reduced adult survival and breeding propensity and has suggested that these processes regulate plover populations on the Missouri River system (Catlin et al. 2019). We studied piping plovers on a broad sample of Missouri River study areas that varied widely in habitat conditions as well as piping plover and least tern nesting abundances. Our results suggest that density dependence is likely not a negative influence on productivity of piping plovers on the Missouri River system. Plovers are capable of dispersal when habitat conditions deteriorate but may be predisposed to return to a breeding location where they were previously successful, artificially inflating densities (Roche et al. 2012). Habitat conditions vary spatially and temporally across the Missouri River, providing opportunities for plovers to disperse and colonize novel habitats in many years. Our data suggest that breeding aggregations of plovers at low abundances in novel habitats would have positive influences on productivity, enabling local population growth. However, the effect of conspecific breeding density (versus abundances) is still unknown. Further work to understand how density dependent processes ultimately affect piping plover population dynamics is necessary.

One limitation of this study was the reliance on a crude measure of presence of conspecifics and heterospecifics, especially during the chick rearing period. On the reservoir especially, this could mean there was an individual nesting over a kilometer away and not be representative of an individual's protected zone. This is less of a concern for the nesting stage, because we used nest counts within varying radii of the focal nest, which were found to better explain nest survival than presence in three of four tests. However, we were unable to estimate this for chicks as the location of chicks was not uniformly recorded. Even with our nest counts, a better measure would be density based on available nesting habitat and more representative of the colony an individual was nesting within. Breeding adult populations of terns and plovers respond to availability of habitat along the Missouri River, increasing dramatically after the creation of riverine sandbars following the 2011 flood (Anteau et al. 2019, Hunt et al. 2019). Nesting habitat is highly variable within and among years due to water management strategies. Because of this, it is difficult to estimate the size of sandbars or amount of habitat on sandbars for a year let alone daily. The importance of our abundance measures for nest survival suggests that density of individuals is likely driving the patterns seen here particularly for plovers. Further, position within the colony (edge versus center) may also influence the risk of predation (Brunton 1997) and nests at a single site may share common risk factors. Future efforts could attempt to address this limitation by estimating habitat patch size and calculating habitat-based densities - particularly for chicks - which may shed light on the potential mechanisms that drive this pattern and attempt to control for spatial autocorrelation that occurs when many individuals nest on single sandbars.

Our data suggest that piping plovers benefit from the anti-predator behaviors of least terns, but this relationship 
does not meet all three requirements of a protective nesting association: 1) the ability to recognize potential protectors, 2) active selection of protected areas and 3) survival benefits that exceed predator swamping (Quinn and Ueta 2008). While plovers nest near a species that exhibits loud, defensive behaviors that are easily detected by other species in the community, active choice cannot be inferred because plovers initiated nests prior to the arrival of terns on the breeding areas. Because of this time lag, neither the presence of active tern nests nor the recognition of terns as a protector species are viable nest-site selection factors for piping plovers initiating their first nests. A similar pattern has been shown with snowy plovers Charadrius nivosus and least terns nesting on the California coast (Powell 2001). Much like the snowy plovers, survival of piping plover nests and chicks was higher after the arrival of least terns, and for GRR and GVP, piping plovers nesting with more least tern nests within $500 \mathrm{~m}$, likely within range of strong antipredator responses by terns, were more likely to hatch. As such, plovers may instead be nesting in similar habitat to terns and passively participating in a mutualistic relationship. Further research into settlement decisions of later nesting individuals (e.g. renests of plovers or first nests for terns) may elucidate the role of recognition and choice in this interaction.

Both least terns and piping plovers select similar nesting habitat that is largely free from vegetation on bare or mostly bare sandbars and shorelines on the Missouri River system. Nest site characteristics, selected or avoided, have been well documented for least terns on river reaches (Sherfy et al. 2012, Stucker et al. 2013) and piping plovers on reservoirs (Anteau et al. 2012a, 2014a), but not vice versa. By and large, nest sites for the two species are similar at the broad or coarse scale; however, they had differing selections for substrate composition (pebbles, gravel and cobble) and plovers utilize a broader suite of microhabitats for nesting (Anteau et al. 2012a, Sherfy et al. 2012, Stucker et al. 2013, Anteau et al. 2014a). Often these specific, selected, habitat features occur near each other in potential breeding areas. Because of this, the heterospecific association formed could indeed be a passive selection by both species for a similar nesting habitat rather than choice to associate with heterospecifics and limited availability of preferred habitat would drive the species into coexistence.

Along the Missouri River, habitat is managed and created for nesting plovers and terns. In the most recent Biological Opinion on management actions for the Missouri River (USFWS 2018), the US Fish and Wildlife Service stated that the primary focus will be to provide sufficient emergent sandbar habitat to ensure viability of plovers as that should ensure habitat for nesting terns as well. However, despite the similar habitat requirements, our results suggest that neither species would benefit from management directed solely at providing habitat for the other. Managing for subtle variations in the substrates (e.g. size and type) on sandbars should result in more robust heterospecific colonies on the Missouri River increasing productivity for both piping plovers and least terns.
Piping plovers and least terns benefit from an asymmetric mutualistic relationship despite varying costs and benefits of associating with conspecifics on the Missouri River. Conspecific cooperation can have an inverse relationship with heterospecific mutualism (Johnstone and Bshary 2002). Asymmetric mutualistic relationships are fairly common in bird-seed dispersal interactions and mixed species foraging flocks (Schleuning et al. 2014, Goodale et al. 2020) and may play important roles in species distribution evolution (Yamamura et al. 2004, Bascompte et al. 2006). Mixed species foraging flocks may also derive benefits from reduced predation risk or for information/access to foraging and have similar cost-benefit interactions with con- and heterospecifics (Sridhar et al. 2013, Sridhar and Shanker 2014). Mixed species foraging groups occur on shorter time scales and shifting spaces than stationary breeding aggregations; however, the majority of species in mixed species flocks benefit from reduced predation risk despite the presence of conspecifics (Sridhar and Shanker 2014) as we show here in a heterospecific breeding aggregation. Despite low benefits, cooperation continues (Johnstone and Bshary 2002). Least terns rarely nested outside of the mutualistic aggregation with piping plovers - only 75 of 1060 least terns nests had no piping plovers present at some point during incubation. Collective decision making for communal foraging resources may provide insight into why individuals choose to breed within heterospecific breeding associations when benefits for individuals are low (Farine et al. 2014b) or the stability of the interaction among species and group living (Goodale et al. 2020). Understanding how species interact with both conand heterospecifics in mixed species colonies over varying spatio-temporal gradients may be an important approach to understand the adaptive value of group living.

Acknowledgements - We thank many field technicians, crew leaders and managers for their assistance with data collection. Our field protocols were approved by the USGS Northern Prairie Wildlife Research Center Animal Care and Use Committee. Any use of trade, product or firm names is for descriptive purposes only and does not imply endorsement by the U.S. government. We appreciate the helpful comments from Veli-Matti Väänänen which greatly improved this manuscript.

Funding - This study was funded by the U.S. Army Corps of Engineers' Missouri River Recovery Program and the USGS Northern Prairie Wildlife Research Center. We are grateful for logistical support from the Corps' Garrison Project, Gavins Point Project, and Threatened and Endangered Species Section as well as from the US Fish and Wildlife Service.

\section{Data availability statement}

Analyses reported in this article can be reproduced using the data provided by Swift et al. (2020b) or be picked up at ScienceBase (<www.sciencebase.gov/cata$\log /$ item/5ea1dc8182cefae35a16ebb6>, doi:10.5066/ P94WA86D.). 


\section{References}

Alberico, J. A. R. et al. 1991. Nesting near a common tern colony increases and decreases spotted sandpiper nest predation. - Auk 108: 904-910.

Alexander, R. D. 1974. The evolution of social behavior. - Annu. Rev. Ecol. Syst. 5: 325-383.

Andersson, M. and Wiklund, C. G. 1978. Clumping versus spacing out: experiments on nest predation in fieldfares (Turdus pilaris). - Anim. Behav. 26: 1207-1212.

Andes, A. K. et al. 2019. Accuracy of nest fate classification and predator identification from evidence at nests of least terns and piping plovers. - Ibis 161: 286-300.

Anteau, M. J. et al. 2012a. Selection indicates preference in diverse habitats: a ground-nesting bird (Charadrius melodus) using reservoir shoreline. - PLoS One 7: e30347.

Anteau, M. J. et al. 2012b. Nest survival of piping plovers at a dynamic reservoir indicated an ecological trap for a threatened population. - Oecologia 170: 1167-1179.

Anteau, M. J. et al. 2014a. Landscape selection by piping plovers has implications for measuring habitat and population size. - Landscape Ecol. 29: 1033-1044.

Anteau, M. J. et al. 2014b. Measuring and predicting abundance and dynamics of habitat for piping plovers on a large reservoir. - Ecol. Model. 272: 16-27.

Anteau, M. J. et al. 2019. Demographic responses of least terns and piping plovers to the 2011 Missouri River flood - a large-scale case study. - US Geological Survey Open File Report 2018-1176.

Aplin, L. M. et al. 2012. Social networks predict patch discovery in a wild population of songbirds. - Proc. R. Soc. B 279: 4199-4205.

Armstrong, D. P. et al. 2002. Obtaining meaningful comparisons of nest success - data from New Zealand robin (Petroica australis) populations. - N. Zeal. J. Ecol. 26: 1-13.

Arnold, T. W. 2010. Uninformative parameters and model selection using Akaike's information criterion. - J. Wildl. Manage. 74: 1175-1178.

Bascompte, J. et al. 2006. Asymmetric coevolutionary networks facilitate biodiversity maintenance. - Science 312: 431-433.

Bêty, J. et al. 2001. Are goose nesting success and lemming cycles linked? Interplay between nest density and predators. - Oikos 93: 388-400.

Brown, C. R. et al. 1990. Choice of colony size in birds. - Trends Ecol. Evol. 5: 398-403.

Brunton, D. H. 1997. Impacts of predators: center nests are less successful than edge nests in a large nesting colony of least terns. - Condor 99: 372-380.

Brunton, D. 1999. 'Optimal' colony size for least terns: an intercolony study of opposing selective pressures by predators. - Condor 101: 607-615.

Burger, J. 1987. Physical and social determinants of nest-site selection in piping plover in New Jersey. - Condor 89: 811-818.

Burnham, K. P. et al. 2011. AIC model selection and multimodel inference in behavioral ecology: some background, observations, and comparisons. - Behav. Ecol. Sociobiol. 65: 23-35.

Buskirk, W. H. 1976. Social-systems in a tropical forest avifauna. - Am. Nat. 110: 293-310.

Catlin, D. H. et al. 2011. Piping plover habitat selection and nest success on natural, managed, and engineered sandbars. - J. Wildl. Manage. 75: 305-310.
Catlin, D. H. et al. 2019. Direct and indirect effects of nesting density on survival and breeding propensity of an endangered shorebird. - Ecosphere 10: e02740.

Campobello, D. et al. 2011. Under my wing: lesser kestrels and jackdaws derive reciprocal benefits in mixed-species colonies. - Behav. Ecol. 23: 425-433.

Chamberlain, S. A. et al. 2014. How context dependent are species interactions? - Ecol. Lett. 17: 881-890.

Doligez, B. et al. 2002. Public information and breeding habitat selection in a wild bird population. - Science 297: 1168-1170.

Elliott-Smith, E. and Haig, S. M. 2004. Piping plover (Charadrius melodus), version 2.0. - In: Poole, A. F. (ed), The birds of North America. Cornell Lab of Ornithology, Ithaca, NY, USA. doi:10.2173/bna.2.

Ellis, J. C. and Good, T. P. 2006. Nest attributes, aggression, and breeding success of gulls in single and mixed species subcolonies. - Condor 108: 211-219.

Farine, D. R. et al. 2014a. Mixed-species associations can arise without heterospecific attraction. - Behav. Ecol. 25: 574-581.

Farine, D. R. et al. 2014b. Collective decision making and social interaction rule in mixed-species flocks of songbirds. - Anim. Behav. 95: 173-182.

Giroux, M. A. et al. 2016. Is it safe to nest near conspicous neighbours? Spatial patterns in predation risk associated with density of American golden-plover nests. - PeerJ 4: e2193.

Goodale, E. et al. 2020. Mixed company: a framework for understanding the composition and organization of mixed-species animal groups. - Biol. Rev. doi:10.1111/brv.12591.

Groom, M. J. 1992. Sand-colored nighthawks parasitize the antipredator behavior of three nesting bird species. - Ecology 73: 785-793.

Haemig, P. D. 2001. Symbiotic nesting of birds with formidable animals: a review with applications to biodiversity conservation. - Biodivers. Conserv. 10: 527-540.

Hamilton, W. D. 1971. Geometry for the selfish herd. - J. Theor. Ecol. 31: 295-311.

Harrison, N. M. and Whitehouse, M. J. 2011. Mixed-species flocks: an example of niche construction? - Anim. Behav. 81: 675-682.

Hunt, K. L. et al. 2019. Demographic response of piping plovers suggests that engineered habitat restoration is no match for natural riverine processes. - Condor 120: 149-165.

Johnstone, R. A. and Bshary, R. 2002. From parasitism to mutualism: partner control in asymmetric interactions. - Ecol. Lett. 5: 634-639.

Krause, J. and Ruxton, G. D. 2002. Living in groups. - Oxford Univ. Press.

Kruse, C. D. 1993. Influence of predation on least tern and piping plover productivity along the Missouri River in South Dakota. - MSci thesis, South Dakota State University.

Laake, J. L. 2013. RMark: an R interface for analysis of capturerecapture data with MARK. - AFSC Processed Rep 2013-01.

Lack, D. 1968. Ecological adaptations for breeding in birds. - Methuen.

Lecomte, N. et al. 2008. Predator behaviour and predation risk in the heterogeneous Arctic environment. - J. Anim. Ecol. 77: 439-447.

Lebreton, J. D. et al. 1992. Modeling survival and testing biological hypotheses using marked animals: a unified approach with case studies. - Ecol. Monogr. 62: 67-118.

Lima, S. L. 2009. Predators and the breeding bird: behavioral and reproductive flexibility under the risk of predation. - Biol. Rev. 84: 485-513. 
Magrath, R. D. et al. 2015. Eavesdropping on heterospecific alarm calls: from mechanisms to consequences. - Biol. Rev. 90: 560-586.

Mayer, P. M. and Ryan, M. R. 1991. Survival rates of artificial piping plover nests in American avocet colonies. - Condor 93: 753-755.

Mouton, J. and Martin, T. E. 2018. Fitness consequences of interspecific nesting associations among cavity-nesting birds. - Am. Nat. 192: 389-396.

Nuechterlein, G. L. 1981. 'Information parasitism' in mixed colonies of western grebes and Forster's terns. - Anim. Behav. 29: 985-989.

Paulson, D. R. and Erckmann, W. J. 1985. Buff-breasted sandpipers nesting in association with black-bellied plovers. - Condor 87: 429-430.

Powell, A. N. 2001. Habitat characteristics and nest success of snowy plovers associated with California least tern colonies. - Condor 103: 785-792.

Phelps, S. M. et al. 2007. The mixed-species chorus as public information: Tungara frogs eavesdrop on a heterospecific. - Behav. Ecol. 18: 108-114.

Pius, S. M. and Leberg, P. L. 1997. Aggression and nest spacing in single and mixed species groups of seabirds. - Oecologia 111: $144-150$.

Pöysä, H. et al. 2019. Collapse of a protector spcies drives secondary endangerment in waterbird communities. - Biol. Conserv. 230: 75-81.

Pratte, I. et al. 2016. Aggressive neighbors and dense nesting: nest site choice and success in high-Arctic common eiders. - Polar Biol. 39: 1597-1604.

Quinn, J. L. and Ueta, M. 2008. Protective nesting associations in birds. - Ibis 150: 146-167.

Roche, E. A. et al. 2012. Flooding affects dispersal decisions in piping plovers (Charadrius melodus) in Prairie Canada. - Auk 129: 296-306.

Roche, E. A. et al. 2014. Detection probability of least tern and piping plover chicks in a large river system. - J. Wildl. Manage. 78: 709-720.

Schleuning, M. et al. 2014. At a loss for birds: insularity increases asymmetry in seed-dispersal networks. - Global Ecol. Biogeogr. 23: 385-394.

Schmidt, K. A. and Whelan, C. J. 1999. Nest predation on woodland songbirds: when is nest predation density dependent? - Oikos 87: 65-74.

Seppänen, J. T. et al. 2007. Social information use is a process across time, space, and ecology, reaching heterospecifics. - Ecology 88: 1622-1633.

Shaffer, T. L. 2004. A unified approach to analyzing nest success. - Auk 121: 526-540.

Shaffer, T. L. et al. 2013. Accuracy of the Missouri River least tern and piping plover monitoring program: considerations for the future. - U.S. Geological Survey Open-File Report 2013-1176.

Sherfy, M. H. et al. 2008. Missouri River emergent sandbar habitat monitoring plan - a conceptual framework for adaptive management. - U.S. Geological Survey Open-File Report 2008-1223.

Sherfy, M. H. et al. 2012. Selection of nest-site habitat by interior least terns in relation to sandbar construction. - J. Wildl. Manage. 76: 363-371.

Supplementary material (available online as Appendix oik07256 at <www.oikosjournal.org/appendix/oik-07256>). Appendix 1.
Sládeček, M. et al. 2014. Coping with nest predation risk in a species-rich bird community inhabiting a Siberian wetland. - Folia Zool. 63: 256-268.

Smith, P. A. et al. 2007. Annual variation in the benefits of a nesting association between red phalaropes (Phalaropus fulicarius) and Sabine's gulls (Xema sabini). - Auk 124: 276-290.

Sridhar, H. et al. 2009. Why do birds participate in mixed-species foraging flocks? A large-scale synthesis. - Anim. Behav. 78: 337-347.

Sridhar, H. et al. 2013. Species importance in a heterospecific foraging association network. - Oikos 122: 1325-1334.

Sridhar, H. and Shanker, K. 2014. Using intra-flock association patterns to understand why birds participate in mixed-species foraging flocks in terrestrial habitats. - Behav. Ecol. Sociobiol. 68: $185-196$.

Stucker, J. et al.e 2013. Consequences of leat tern (Sternula antillarum) microhabitat nest-site seleciton on natural and mechanically constructed sandbars in the Missouri River. - Auk 130: 753-763.

Swift, R. J. et al. 2018. Context-dependent costs and benefits of a heterospecific nesting association. - Behav. Ecol. 29: 974-983.

Swift, R. J. et al. 2020a. Low renesting propensity and reproductive success make renesting unproductive for the threatened piping plover, Charadrius melodus. - Condor. 122: duz066.

Swift, R. J. et al. 2020b. Hetero- and conspecific effects on nest and chick survival for two listed species; piping plover and least tern breeding on the Missouri River, USA 2007-2016. - U.S. Geological Survey data release. doi:10.5066/ P94WA86D.

Thompson, B. C. et al. 1997. Least tern (Sternula antillarum), ver. 2.0. - In: Poole, A. F. and Gill, F. B. (eds), The birds of North America. Cornell Lab of Ornithology, Ithaca, NY, USA. doi: 10.2173/bna.290

U.S. Fish and Wildlife Service (USFWS) 2018. Biological opinion. Operation of the Missouri River mainstem reservoir system, the operation and maintenance of the bank stabilization and navigation project, the operation of Kansas River reservoir system, and the implementation of the Missouri River recovery management plan. - USFWS, Denver, Colorado.

Väänänen, V.-M. 2000. Predation risk associated with nesting in gull colonies by two Aythya species: observations and an experimental test. - J. Avian Biol. 31: 31-35.

Väänänen, V.-M. et al. 2016. Nest and brood stage association between ducks and small colonial gulls in boreal wetlands. - Ornis Fenn. 93: 47-54.

Varela, S. A. M. et al. 2007. Does predation select for or against avian coloniality? A comparative analysis. - J. Evol. Biol. 20: 1490-1503.

Ward, P. and Zahavi, A. 1973. The importance of certain assemblages of birds as 'information-centres' for food-finding. - Ibis 115: 517-534.

White, G. C. and Burnham, K. P. 1999. Program MARK: survival estimation from populations of marked animals. - Bird Study 46: S120-S139.

Yamamura, N. et al. 2004. Evolution of mutualism through spatial effects. - J. Theor. Biol. 226: 421-428. 


\section{OIK-07256}

Swift, R. J., Anteau, M. J., Roche, E. A., Sherfy, M. H., Toy, D. L. and Ring, M. M. 2020. Asymmetric benefits of a heterospecific breeding association vary with habitat, conspecific abundance, and breeding stage. - Oikos doi: 10.1111/oik.07256

\section{Appendix 1}

Table A1. Top daily nest survival models for piping plovers nesting on the Garrison River Reach (2007, 20122016). AlCc for top model is 2608.37.

\begin{tabular}{llccccc}
\hline$\#$ & Model $(\boldsymbol{S})$ & $\mathbf{K}$ & $\mathbf{\Delta A I C}_{\mathbf{c}}$ & $\mathbf{w}_{\mathbf{i}}$ & Deviance & Step \\
\hline 1 & pp:tp + age $\times$ year + date $\times$ year & 21 & 0.00 & 1.00 & 2566.19 & 3 \\
2 & age $\times$ year + date $\times$ year & 18 & 48.20 & 0.00 & 2620.43 & 2 \\
3 & age + date & 3 & 201.94 & 0.00 & 2804.31 & 1 \\
4 & constant & 1 & 257.31 & 0.00 & 2863.68 & 1 \\
\hline
\end{tabular}

Table A2. Top daily nest survival models for piping plovers nesting on Lake Sakakawea (2007-2008, 20122016). AlCc for top model is 1999.33.

\begin{tabular}{llccccc}
\hline$\#$ & Model $(\boldsymbol{S})$ & $\mathbf{K}$ & $\mathbf{\Delta A I C}_{\mathbf{c}}$ & $\mathbf{w}_{\mathbf{i}}$ & Deviance & Step \\
\hline 1 & pp:tp + age $\times$ year + date $\times$ year + elevation $\times$ year & 31 & 0.00 & 1.00 & 1936.74 & 3 \\
2 & age $\times$ year + date $\times$ year + elevation $\times$ year & 28 & 22.86 & 0.00 & 1965.71 & 2 \\
3 & age + date + elevation & 4 & 156.30 & 0.00 & 2147.61 & 1 \\
4 & constant & 1 & 307.72 & 0.00 & 2305.05 & 1 \\
\hline
\end{tabular}

Table A3. Top daily nest survival models for piping plovers nesting on the Gavins Point Reach (2008-2009). AlCc for top model is 1300.05 .

\begin{tabular}{llccccc}
\hline$\#$ & Model $(\boldsymbol{S})$ & $\mathbf{K}$ & $\mathbf{\Delta A I C}_{\mathbf{c}}$ & $\mathbf{w}_{\mathbf{i}}$ & Deviance & Step \\
\hline 1 & pp:tp + age $\times$ year + date $\times$ year + sandbartype $\times$ year & 11 & 0.00 & 1.00 & 1277.96 & 3 \\
2 & age $\times$ year + date $\times$ year + sandbartype $\times$ year & 8 & 31.57 & 0.00 & 1315.57 & 2 \\
3 & age + date + sandbartype & 4 & 49.01 & 0.00 & 1341.04 & 1 \\
4 & constant & 1 & 101.22 & 0.00 & 1399.27 & 1 \\
\hline
\end{tabular}


Table A4. Abundance buffer nest survival models for piping plovers nesting on the Garrison River Reach (2007, 2012-2016). AlCc for top model is 2514.24.

\begin{tabular}{llccccc}
\hline$\#$ & Model $(\boldsymbol{S})$ & $\mathbf{K}$ & $\boldsymbol{\Delta} \mathbf{A I C}_{\mathbf{c}}$ & $\mathbf{W}_{\mathbf{i}}$ & Deviance & Step \\
\hline 1 & tn500 + pn500 + age $\times$ year + date $\times$ year & 20 & 0.00 & 1.00 & 2474.07 & 4 \\
2 & tn200 + pn200 + age $\times$ year + date $\times$ year & 20 & 35.92 & 0.00 & 2509.99 & 4 \\
3 & tn100 + pn100 + age $\times$ year + date $\times$ year & 20 & 70.12 & 0.00 & 2544.19 & 4 \\
4 & pp:tp + age $\times$ year + date $\times$ year & 21 & 94.13 & 0.00 & 2566.19 & 3 \\
5 & tn50 + pn50 + age $\times$ year + date $\times$ year & 20 & 104.50 & 0.00 & 2578.58 & 4 \\
6 & tn5 + pn5 + age $\times$ year + date $\times$ year & 20 & 141.74 & 0.00 & 2615.81 & 4 \\
7 & age $\times$ year + date $\times$ year & 18 & 142.32 & 0.00 & 2620.43 & 2 \\
8 & tn10 + pn10 + age $\times$ year + date $\times$ year & 20 & 143.34 & 0.00 & 2617.42 & 4 \\
\hline
\end{tabular}

Table A5. Abundance buffer daily nest survival models for piping plovers nesting on Lake Sakakawea (20072008, 2012-2016). AlCc for top model is 1999.33.

\begin{tabular}{clccccc}
\hline$\#$ & Model $(\boldsymbol{S})$ & $\mathbf{K}$ & $\mathbf{\Delta} \mathbf{A I C}_{\mathbf{c}}$ & $\mathbf{w}_{\mathbf{i}}$ & Deviance & Step \\
\hline 1 & pp:tp + age $\times$ year + date $\times$ year + elevation $\times$ year & 31 & 0.00 & 0.70 & 1936.74 & 3 \\
2 & tn100 + pn100 + age $\times$ year + date $\times$ year + elevation $\times$ year & 30 & 3.59 & 0.12 & 1942.36 & 4 \\
3 & tn500 + pn500 + age $\times$ year + date $\times$ year + elevation $\times$ year & 30 & 4.23 & 0.08 & 1943.01 & 4 \\
4 & tn50 + pn50 + age $\times$ year + date $\times$ year + elevation $\times$ year & 30 & 4.26 & 0.08 & 1943.04 & 4 \\
5 & tn200 + pn200 + age $\times$ year + date $\times$ year + elevation $\times$ year & 30 & 7.12 & 0.02 & 1945.9 & 4 \\
6 & tn10 + pn10 + age $\times$ year + date $\times$ year + elevation $\times$ year & 30 & 14.34 & 0.00 & 1953.12 & 4 \\
7 & tn5 + pn5 + age $\times$ year + date $\times$ year + elevation $\times$ year & 30 & 17.56 & 0.00 & 1956.34 & 4 \\
8 & age $\times$ year + date $\times$ year + elevation $\times$ year & 28 & 22.86 & 0.00 & 1965.71 & 2 \\
\hline
\end{tabular}

Table A6. Abundance buffer nest survival models for piping plovers nesting on the Gavins Point Reach (2008-2009). AICc for top model is 1219.04.

\begin{tabular}{|c|c|c|c|c|c|c|}
\hline$\#$ & Model $(S)$ & K & $\Delta \mathrm{AIC}_{\mathrm{c}}$ & $\mathbf{w}_{\mathrm{i}}$ & Deviance & Step \\
\hline 1 & $\begin{array}{l}\text { tn500 }+ \text { pn500 + age } \times \text { year }+ \text { date } \times \text { year }+ \text { sandbartype } \times \\
\text { year }\end{array}$ & 10 & 0.00 & 1.00 & 1198.97 & 4 \\
\hline 2 & $\begin{array}{l}\text { tn200+pn200 + age } \times \text { year }+ \text { date } \times \text { year }+ \text { sandbartype } \times \\
\text { year }\end{array}$ & 10 & 30.28 & 0.00 & 1229.25 & 4 \\
\hline 3 & $\begin{array}{l}\text { tn100 }+ \text { pn100 + age } \times \text { year }+ \text { date } \times \text { year }+ \text { sandbartype } \times \\
\text { year }\end{array}$ & 10 & 63.97 & 0.00 & 1262.94 & 4 \\
\hline 4 & pp:tp + age $\times$ year + date $\times$ year + sandbartype $\times$ year & 11 & 81.01 & 0.00 & 1277.96 & 3 \\
\hline 5 & $\begin{array}{l}\text { tn } 50+\text { pn } 50+\text { age } \times \text { year }+ \text { date } \times \text { year }+ \text { sandbartype } \times \\
\text { year }\end{array}$ & 10 & 91.82 & 0.00 & 1290.79 & 4 \\
\hline 6 & $\begin{array}{l}\operatorname{tn} 10+\operatorname{pn} 10+\text { age } \times \text { year }+ \text { date } \times \text { year }+ \text { sandbartype } \times \\
\text { year }\end{array}$ & 10 & 110.90 & 0.00 & 1309.87 & 4 \\
\hline 7 & age $\times$ year + date $\times$ year + sandbartype $\times$ year & 8 & 112.58 & 0.00 & 1315.57 & 2 \\
\hline 8 & tn5 + pn $5+$ age $\times$ year + date $\times$ year + sandbartype $\times$ year & 10 & 113.68 & 0.00 & 1312.65 & 4 \\
\hline
\end{tabular}


Table A7. Top ranked models for the daily apparent survival of piping plover chicks hatched on the Garrison River Reach. For all models detection probability was parameterized as [ $p$ (prefledge:age $\times$ year + prefledge:year + postfledge)]. QAICc for top model is 5893.02. Measure of overdispersion is 2.15 .

\begin{tabular}{|c|c|c|c|c|c|c|}
\hline \# & Model ( $\phi)$ & K & $\Delta$ QAIC $_{\mathrm{c}}$ & $\mathbf{w}_{\mathbf{i}}$ & QDeviance & Step \\
\hline 1 & tp:prefledge + age:year:prefledge + date:year:prefledge + year:prefledge + postfledge & 33 & 0.00 & 0.55 & 5826.49 & 4 \\
\hline 2 & tp:prefledge + pp:prefledge + age:year:prefledge + date:year:prefledge + year:prefledge + postfledge & 34 & 0.96 & 0.34 & 5825.42 & 4 \\
\hline 3 & age:year:prefledge + date:year:prefledge + year:prefledge + postfledge & 32 & 3.80 & 0.08 & 5832.03 & 3 \\
\hline 4 & pp:prefledge + age:year:prefledge + date:year:prefledge + year:prefledge + postfledge & 33 & 5.51 & 0.03 & 5831.99 & 4 \\
\hline 5 & age:prefledge + date:prefledge + prefledge + postfledge & 17 & 102.65 & 0.00 & 5961.53 & 2 \\
\hline 6 & prefledge + postfledge & 15 & 102.68 & 0.00 & 4500.67 & 2 \\
\hline
\end{tabular}

Table A8. Top ranked models for the daily apparent survival of piping plover chicks hatched on Lake Sakakawea. For all models detection probability was parameterized as [p(prefledge:age + prefledge:year + postfledge)]. QAICc for top model is 2636.79. Measure of overdispersion is 3.17 .

\begin{tabular}{clccccc}
\hline$\#$ & Model ( $\phi)$ & $\mathbf{K}$ & $\Delta \mathbf{Q A I C}_{\mathbf{c}}$ & $\mathbf{W}_{\mathrm{i}}$ & QDeviance & Step \\
\hline 1 & tp:prefledge + year:prefledge + postfledge & 18 & 0.00 & 0.48 & 2600.58 & 4 \\
2 & tp:prefledge + pp:prefledge + year:prefledge + postfledge & 19 & 0.84 & 0.31 & 2599.39 & 4 \\
3 & pp:prefledge + year:prefledge + postfledge & 18 & 3.25 & 0.09 & 2603.83 & 4 \\
4 & year:prefledge + postfledge & 17 & 3.46 & 0.08 & 2049.94 & 3 \\
5 & prefledge + postfledge & 11 & 5.46 & 0.03 & 2064.04 & 2 \\
\hline
\end{tabular}

Table A9. Top ranked models for the daily apparent survival of piping plover chicks hatched on Gavins Point Reach. For all models detection probability was parameterized as [p(prefledge:age + prefledge:year + postfledge)]. QAICc for top model is 4208.05 . Measure of overdispersion is 2.36 .

\begin{tabular}{|c|c|c|c|c|c|c|}
\hline \# & Model ( $\phi)$ & $\mathbf{K}$ & $\triangle$ QAIC $_{\mathrm{c}}$ & $\mathbf{w}_{\mathbf{i}}$ & QDeviance & Step \\
\hline 1 & age:year:prefledge + date:year:prefledge + year:prefledge + postfledge & 11 & 0.00 & 0.53 & 4185.97 & 3 \\
\hline 2 & pp:prefledge + age:year:prefledge + date:year:prefledge + year:prefledge + postfledge & 12 & 1.93 & 0.20 & 4185.88 & 4 \\
\hline 3 & tp:prefledge + age:year:prefledge + date:year:prefledge + year:prefledge + postfledge & 12 & 1.97 & 0.20 & 4185.92 & 4 \\
\hline 4 & tp:prefledge + pp:prefledge + age:year:prefledge + date:year:prefledge + year:prefledge + postfledge & 13 & 3.92 & 0.07 & 4185.86 & 4 \\
\hline 5 & age:prefledge + date:prefledge + prefledge + postfledge & 8 & 11.76 & 0.00 & 4203.76 & 2 \\
\hline 6 & prefledge + postfledge & 6 & 21.63 & 0.00 & 2796.71 & 2 \\
\hline
\end{tabular}


Table A10. Top daily nest survival models for least terns nesting on the Garrison River Reach (2007, 20122016). AlCc for top model is 640.96 .

\begin{tabular}{llccccc}
\hline$\#$ & Model $(\boldsymbol{S})$ & $\mathbf{K}$ & $\mathbf{\Delta A I C}_{\mathbf{c}}$ & $\mathbf{W}_{\mathbf{i}}$ & Deviance & Step \\
\hline 1 & pp:tp + age $\times$ year & 15 & 0.00 & 0.66 & 607.22 & 3 \\
2 & age $\times$ year & 12 & 1.34 & 0.34 & 614.65 & 2 \\
3 & age & 2 & 21.68 & 0.00 & 655.15 & 1 \\
4 & constant & 1 & 22.57 & 0.00 & 658.05 & 1 \\
\hline
\end{tabular}

Table A11. Top daily nest survival models for least terns nesting on Lake Sakakawea (2007-2008, 20122016). AlCc for top model is 111.76.

\begin{tabular}{llccccc}
\hline$\#$ & Model $(\boldsymbol{S})$ & $\mathbf{K}$ & $\Delta$ AIC $_{\mathbf{c}}$ & $\mathbf{w}_{\mathbf{i}}$ & Deviance & Step \\
\hline 1 & age + date & 3 & 0.00 & 0.86 & 105.68 & 1 \\
2 & pp:tp + age + date & 6 & 4.12 & 0.11 & 103.59 & 3 \\
4 & constant & 1 & 6.80 & 0.03 & 116.55 & 1 \\
\hline
\end{tabular}

Table A12. Top daily nest survival models for least terns nesting on Gavins Point Reach (2008-2009). AICc for top model is 239.49 .

\begin{tabular}{clccccc}
\hline$\#$ & Model (S) & $\mathbf{K}$ & $\boldsymbol{\Delta}$ AIC $_{\mathbf{c}}$ & $\mathbf{w}_{\mathbf{i}}$ & Deviance & Step \\
\hline 1 & age + date & 3 & 0.00 & 0.75 & 233.47 & 1 \\
2 & pp:tp + age + date & 6 & 2.32 & 0.23 & 229.76 & 3 \\
4 & constant & 1 & 7.34 & 0.02 & 244.83 & 1 \\
\hline
\end{tabular}

Table A13. Abundance buffer distances daily nest survival models for least terns nesting on the Garrison River Reach (2007, 2012-2016). AICc for top model is 636.24.

\begin{tabular}{clccccc}
\hline$\#$ & Model $(\boldsymbol{S})$ & $\mathbf{K}$ & $\mathbf{\Delta} \mathbf{A I}_{\mathbf{c}}$ & $\mathbf{w}_{\mathbf{i}}$ & Deviance & Step \\
\hline 1 & pn100 + tn100 + age $\times$ year & 14 & 0.00 & 0.38 & 608.02 & 4 \\
2 & pp:tp + age $\times$ year & 15 & 1.24 & 0.20 & 607.22 & 3 \\
3 & pn200 + tn200 + age $\times$ year & 14 & 1.40 & 0.19 & 609.41 & 4 \\
4 & age $\times$ year & 12 & 2.57 & 0.10 & 614.65 & 2 \\
5 & pn500 + tn500 + age $\times$ year & 14 & 3.86 & 0.05 & 611.87 & 4 \\
6 & pn50 + tn50 + age $\times$ year & 14 & 4.75 & 0.03 & 612.77 & 4 \\
7 & pn10 + tn10 + age $\times$ year & 14 & 5.27 & 0.03 & 613.29 & 4 \\
8 & pn5 + tn5 + age $\times$ year & 14 & 6.67 & 0.02 & 614.38 & 4 \\
\hline
\end{tabular}


Table A14. Top ranked models for the daily apparent survival of least tern chicks hatched on the Garrison River Reach. For all models detection probability was parameterized as [ $p$ (age:year:prefledge + prefledge:year + postfledge)]. AICc for top model is 5278.43 . Measure of overdispersion is 1.

\begin{tabular}{|c|c|c|c|c|c|c|}
\hline$\#$ & Model ( $\phi)$ & K & $\mathrm{AIC}_{\mathrm{c}}$ & $\mathbf{w}_{\mathbf{i}}$ & Deviance & Step \\
\hline 1 & tp:prefledge + date:year:prefledge + year:prefledge + postfledge & 27 & 0.00 & 0.57 & 5218.55 & 4 \\
\hline 2 & pp:prefledge + tp:prefledge + date:year:prefledge + year:prefledge + postfledge & 28 & 1.02 & 0.34 & 5117.50 & 4 \\
\hline 3 & date:year:prefledge + year:prefledge + postfledge & 26 & 4.97 & 0.05 & 5225.59 & 3 \\
\hline 4 & pp:prefledge + date:year:prefledge + year:prefledge + postfledge & 27 & 5.42 & 0.04 & 5223.97 & 4 \\
\hline 5 & date:prefledge + prefledge + postfledge & 16 & 123.84 & 0.00 & 5364.97 & 2 \\
\hline 6 & prefledge + postfledge & 15 & 126.47 & 0.00 & 3446.30 & 2 \\
\hline
\end{tabular}

Table A15. Top ranked models for the daily apparent survival of least tern chicks hatched on Lake Sakakawea. For all models detection probability was parameterized as [p(prefledge + postfledge)]. AlCc for top model is 404.74. Measure of overdispersion is 1 .

\begin{tabular}{llccccc}
\hline$\#$ & Model (\$) & $\mathbf{K}$ & $\mathbf{\Delta A I C}_{\mathbf{c}}$ & $\mathbf{w}_{\mathbf{i}}$ & Deviance & Step \\
\hline 1 & age:prefledge + postfledge & 5 & 0.00 & 0.54 & 310.65 & 3,4 \\
2 & prefledge + postfledge & 5 & 1.31 & 0.28 & 311.96 & 4 \\
3 & pp:prefledge + age:prefledge + postfledge & 6 & 2.12 & 0.18 & 394.29 & 2 \\
\hline
\end{tabular}

Table A16. Top ranked models for the daily apparent survival of least tern chicks hatched on the Gavins Point Reach. For all models detection probability was parameterized as [ $p$ (age:prefledge + year:prefledge + postfledge)]. QAICc for top model is 2762.45. Measure of overdispersion is 1.79 .

\begin{tabular}{llccccc}
\hline$\#$ & Model (ф) & $\mathbf{K}$ & $\mathbf{Q A I C}_{\mathbf{c}}$ & $\mathbf{w}_{\mathbf{i}}$ & Deviance $^{\text {Step }}$ \\
\hline 1 & tp:prefledge + year:prefledge + postfledge & 20 & 0.00 & 0.36 & 2720.91 & 4 \\
2 & pp:prefledge + tp:prefledge + year:prefledge + postfledge & 21 & 0.43 & 0.30 & 2719.29 & 4 \\
3 & pp:prefledge + year:prefledge + postfledge & 20 & 1.05 & 0.21 & 2721.97 & 4 \\
4 & year:prefledge + postfledge & 19 & 2.03 & 0.13 & 2214.59 & 3 \\
5 & prefledge + postfledge & 12 & 17.66 & 0.00 & 2244.48 & 2 \\
\hline
\end{tabular}




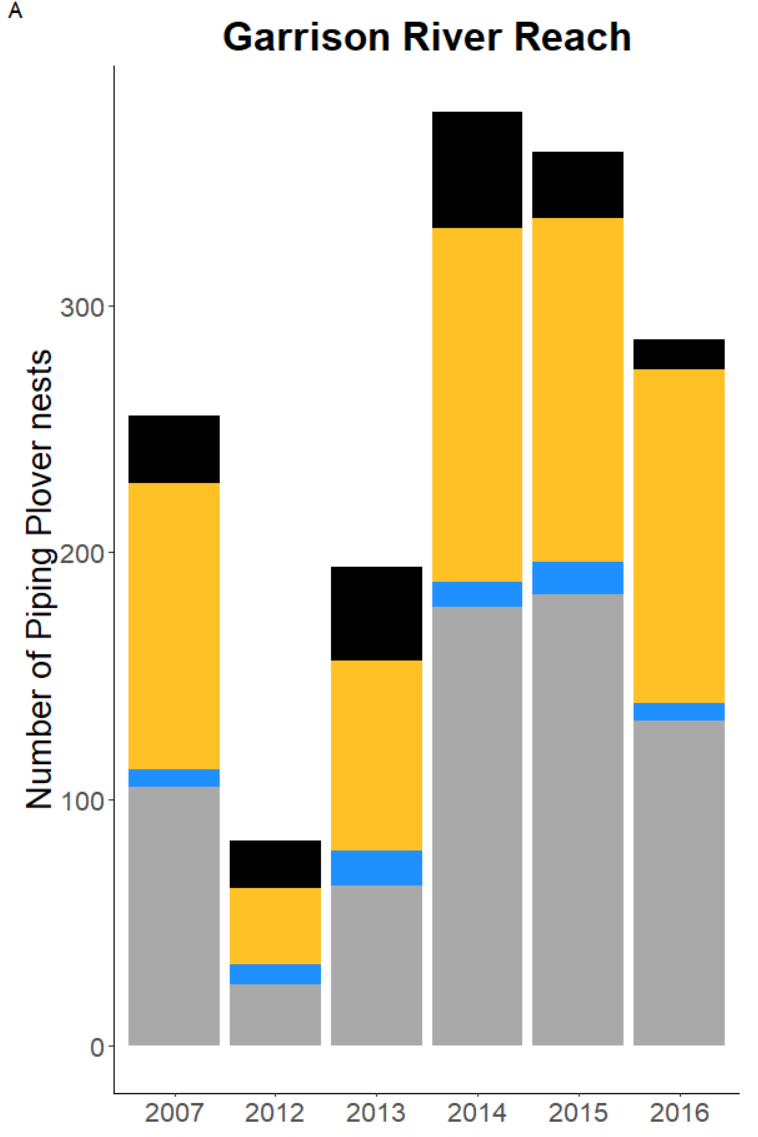

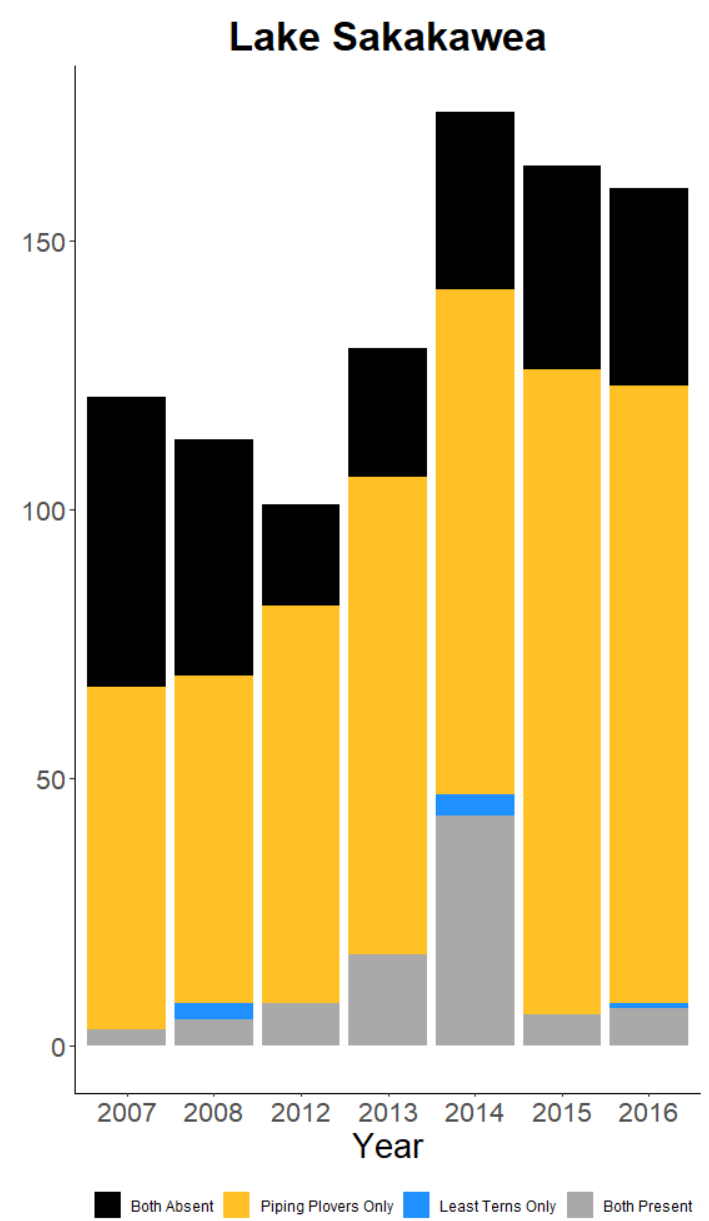

C
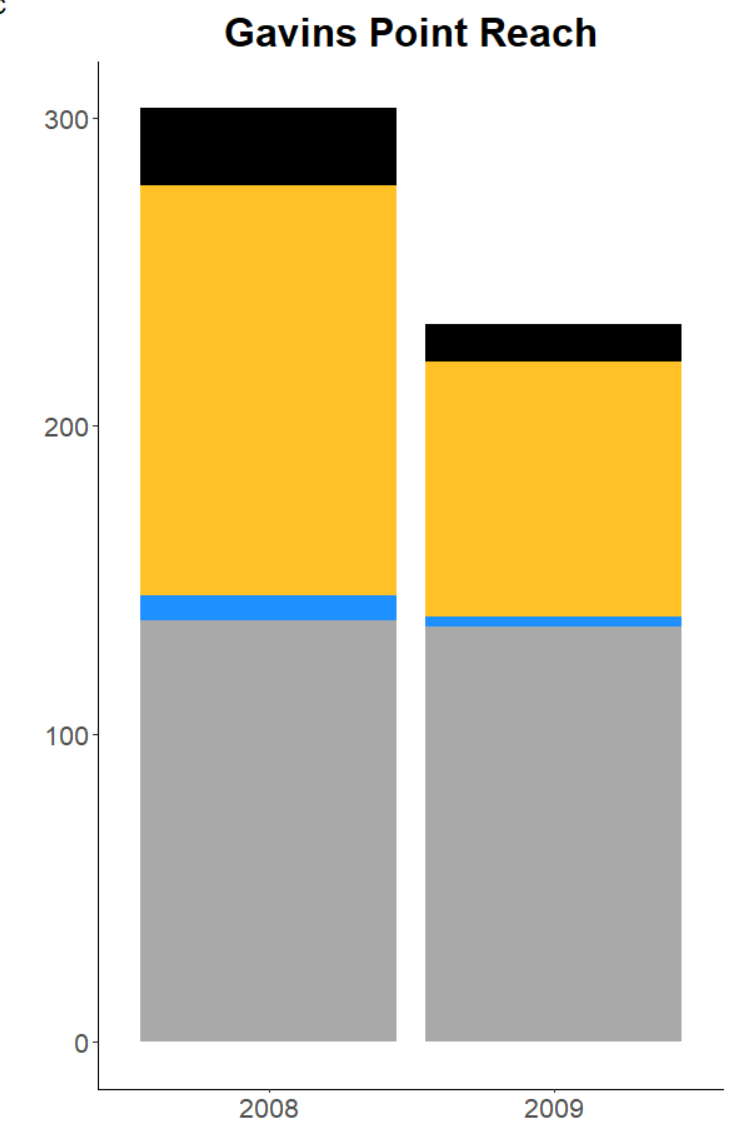

Figure A1. Number of piping plover nests initiated on sandbars/segments relative to the presence of breeding least terns and other breeding piping plovers a) on the Garrison River Reach (2007, 2012-2016), b) on Lake Sakakawea (2007-2008, 2012-2016), and c) on Gavins Point Reach (2008-2009). Note the y-axis scale changes has breeding abundances differ among study areas. 

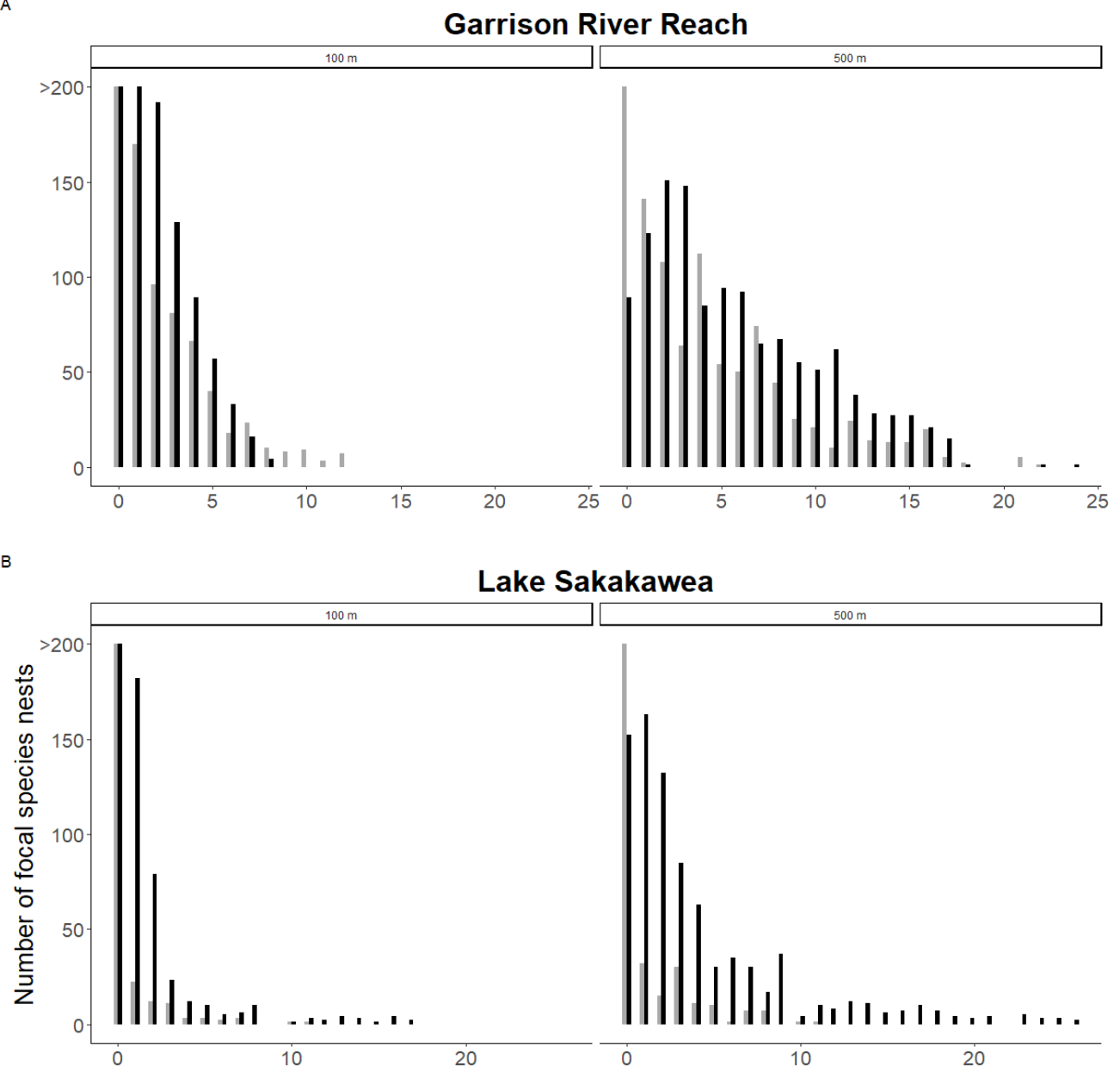

C

Gavins Point Reach

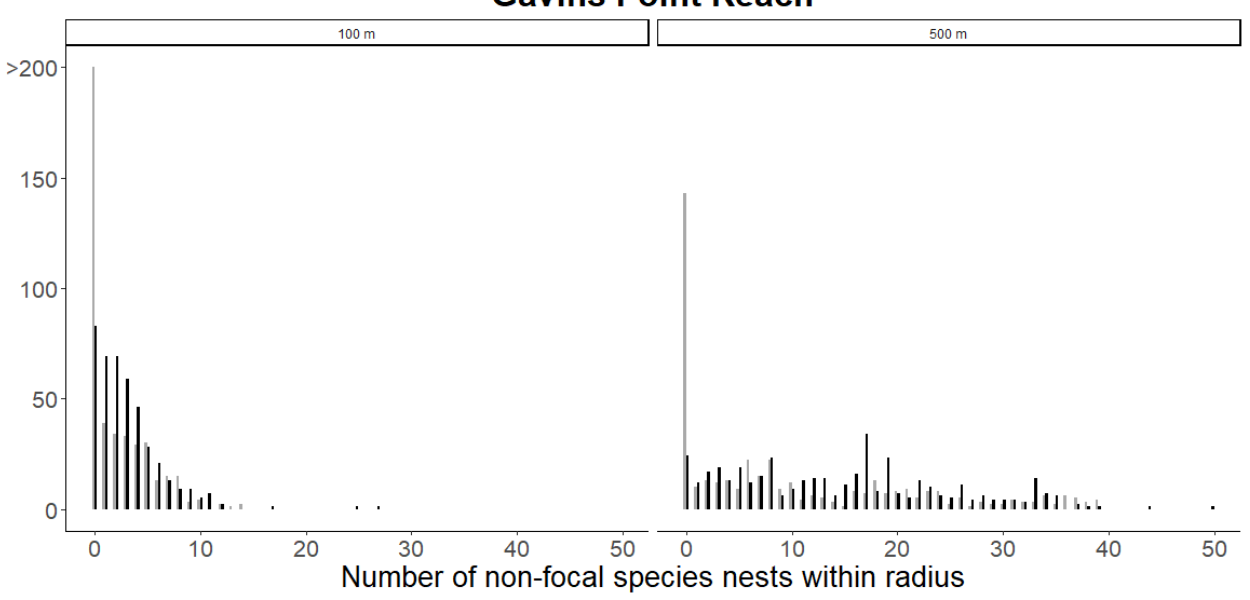

Figure A2. Number of non-focal species nests within 100 meters and 500 meters of the focal species nest for a) Garrison River Reach, b) Lake Sakakawea, and c) Gavins Point Reach. For example, on Garrison River Reach, for 40 least tern nests (gray), five piping plover nests were within $100 \mathrm{~m}$; for 57 piping plover nests (black), five least tern nests were within $100 \mathrm{~m}$. Note the $\mathrm{x}$-axis scale changes has breeding abundances differ among study areas. 

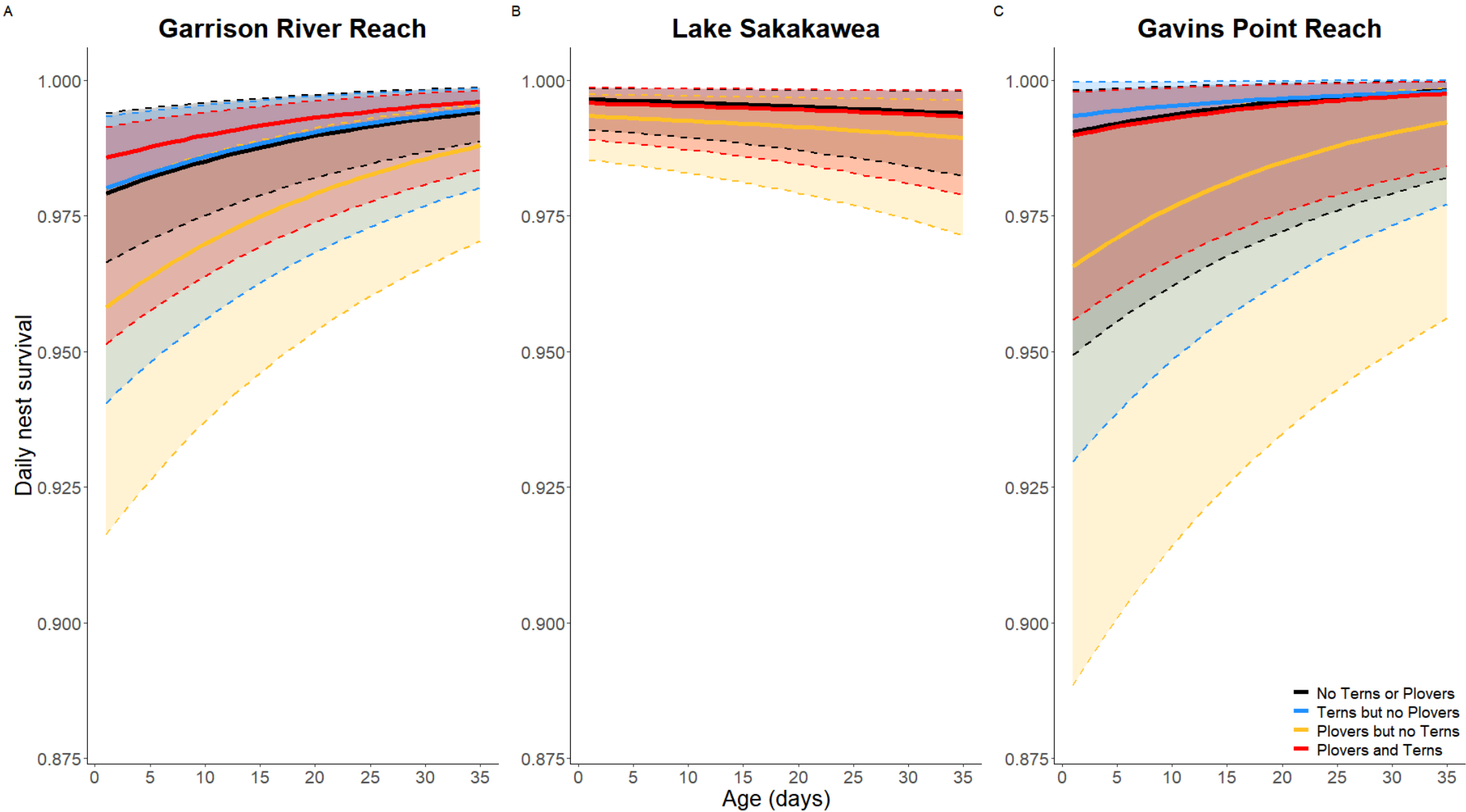

Figure A3. Daily nest survival to hatching (35 days) of Piping Plover nests on a) the Garrison River Reach, b) Lake Sakakawea, and c) Gavins Point Reach relative to the presence of other piping plovers and least terns during the nesting period by nest age. Shaded polygons represent $95 \%$ confidence envelopes for the predicted daily apparent survival values for nest survival when terns and plovers were both present (red), when only other plovers were present (yellow), only terns were present (blue) and when no terns nor other plovers were present (black). Daily nest survival estimates were generated using the top-supported model with covariates set to their mean values a) $[S(p p: t p+$ age $\times$ year + date $\times$ year $)]$, b) $[S(p p: t p+$ age $\times$ year + date $\times$ year + elevation $\times$ year $)]$, and c) $[S(p p: t p+$ age $\times$ year + date $\times$ year + sandbartype $\times$ year $)]$. 

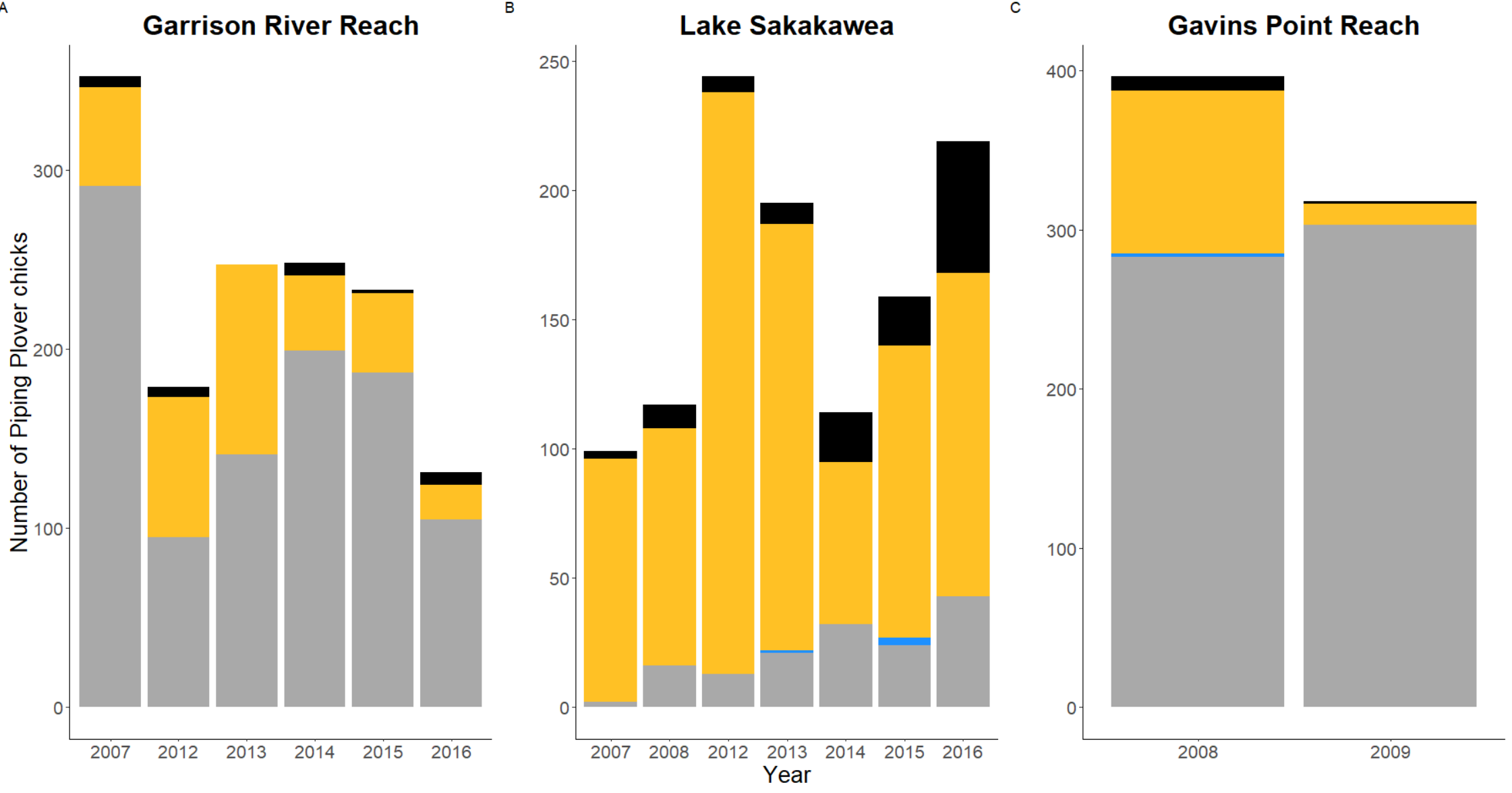

Figure A4. Number of piping plover chicks raised on sandbars/segments in the presence of breeding least terns and/or piping plovers on the a) Garrison River Reach (2007, 2012-2016), b) Lake Sakakawea (2007-2008, 2012-2016), c) Gavins Point Reach (2008-2009). Note the y-axis scale changes as breeding abundances vary among study areas. 


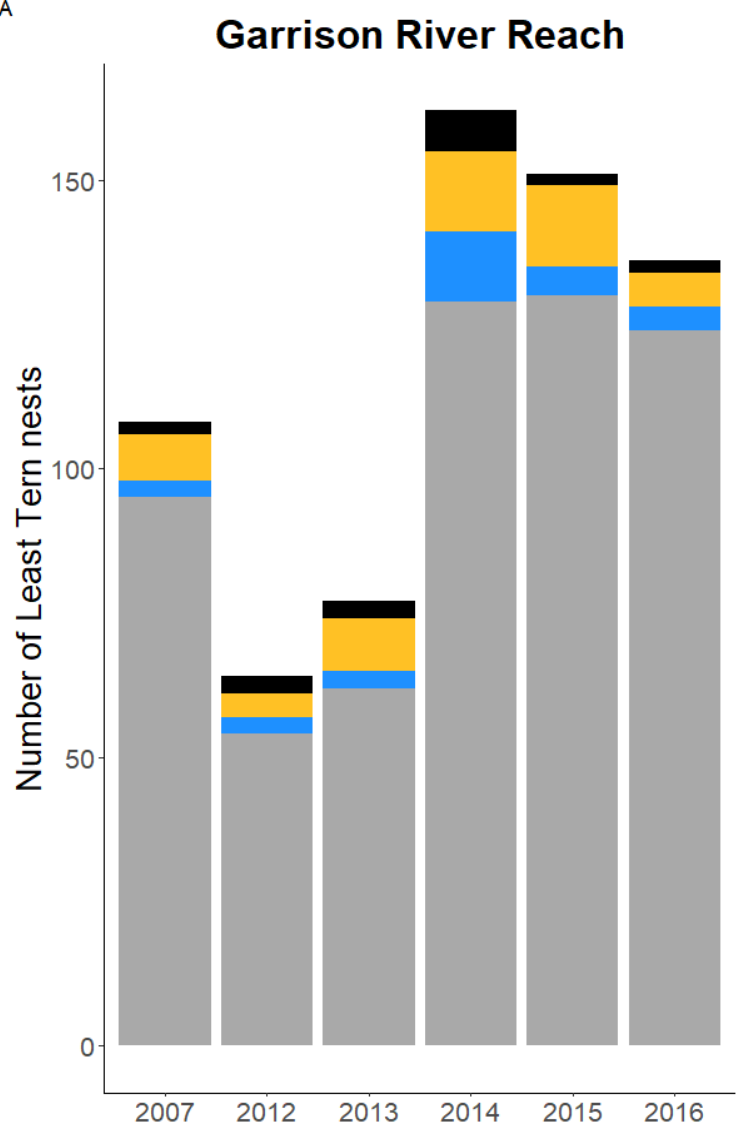

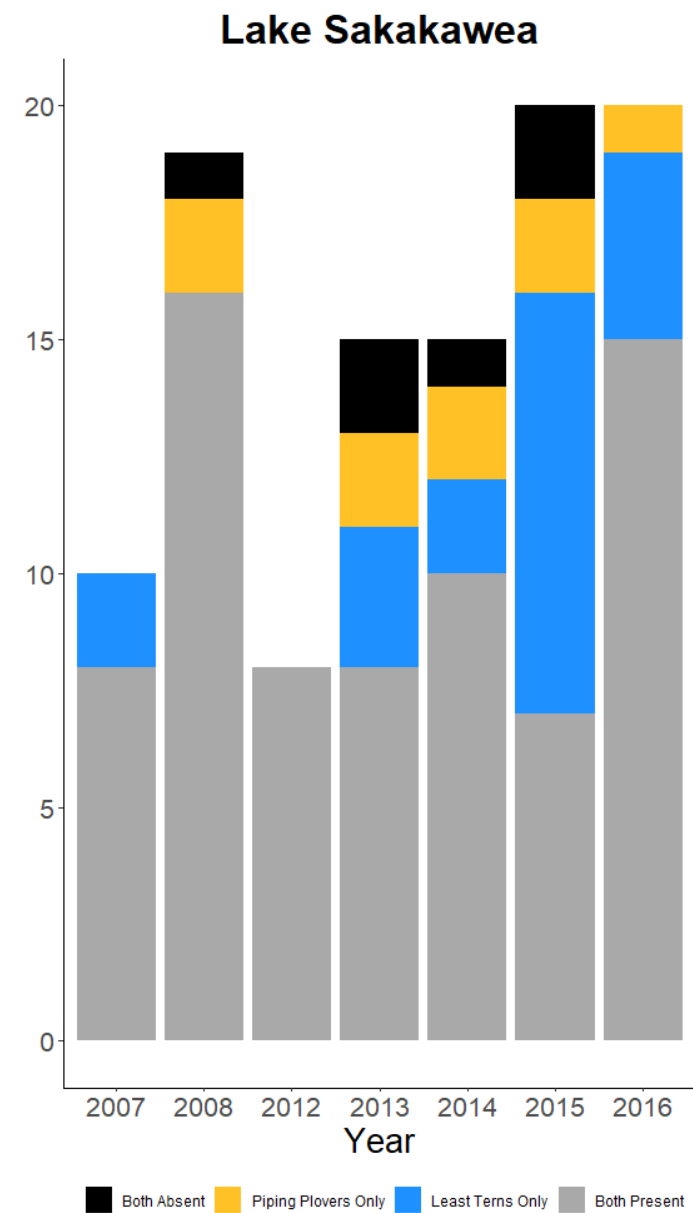

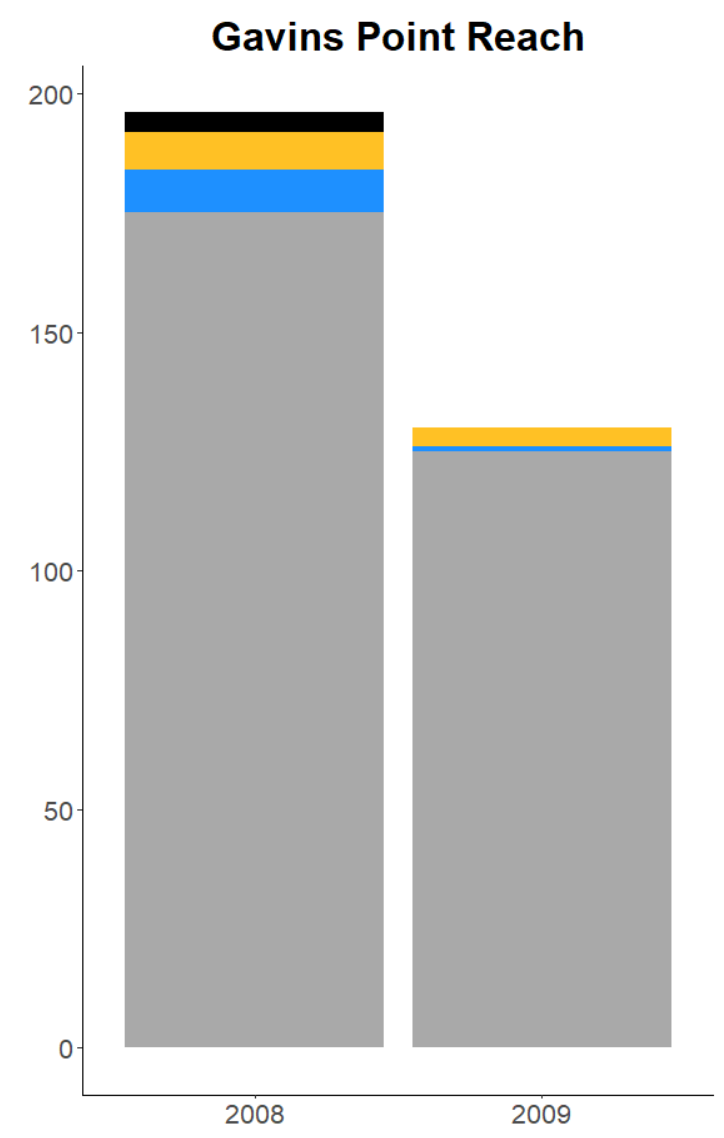

Figure A5. Number of least tern nests initiated on sandbars/segments relative to the presence of breeding piping plovers and other breeding least terns a) on the Garrison River Reach (2007, 2012-2016), b) on Lake Sakakawea (2007-2008, 2012-2016), and c) on the Gavins Point Reach (2008-2009). Note the y-axis scale changes as breeding abundances vary among study areas. 


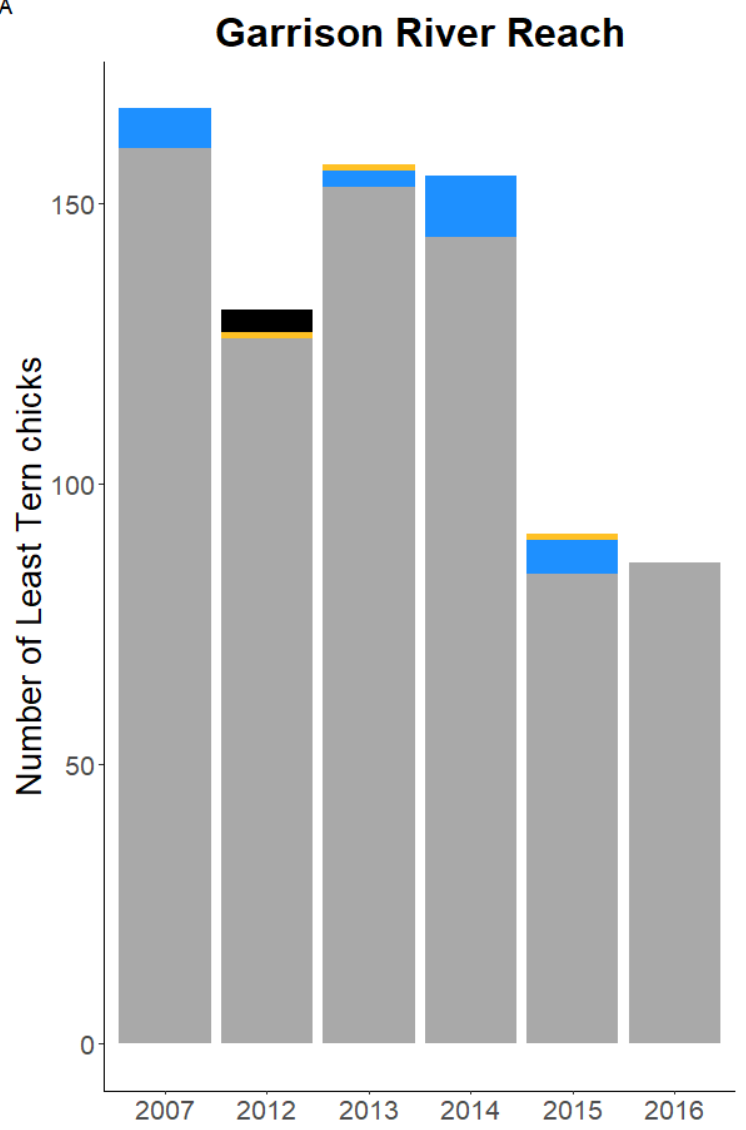

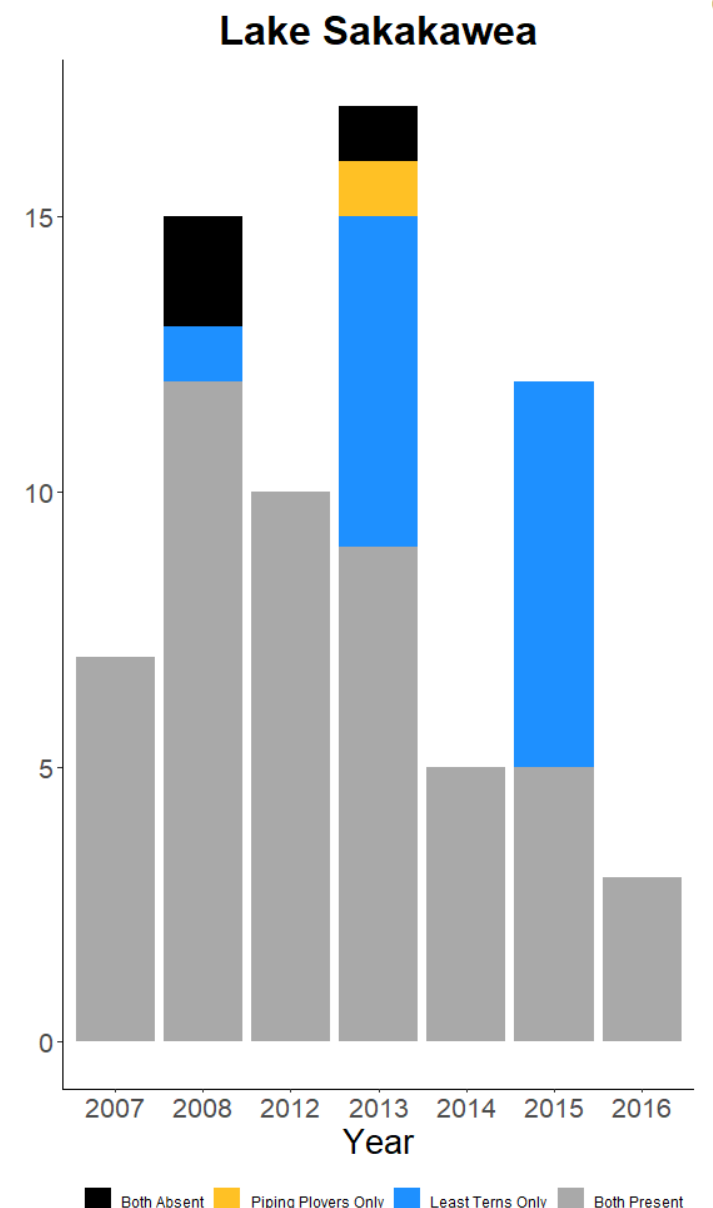

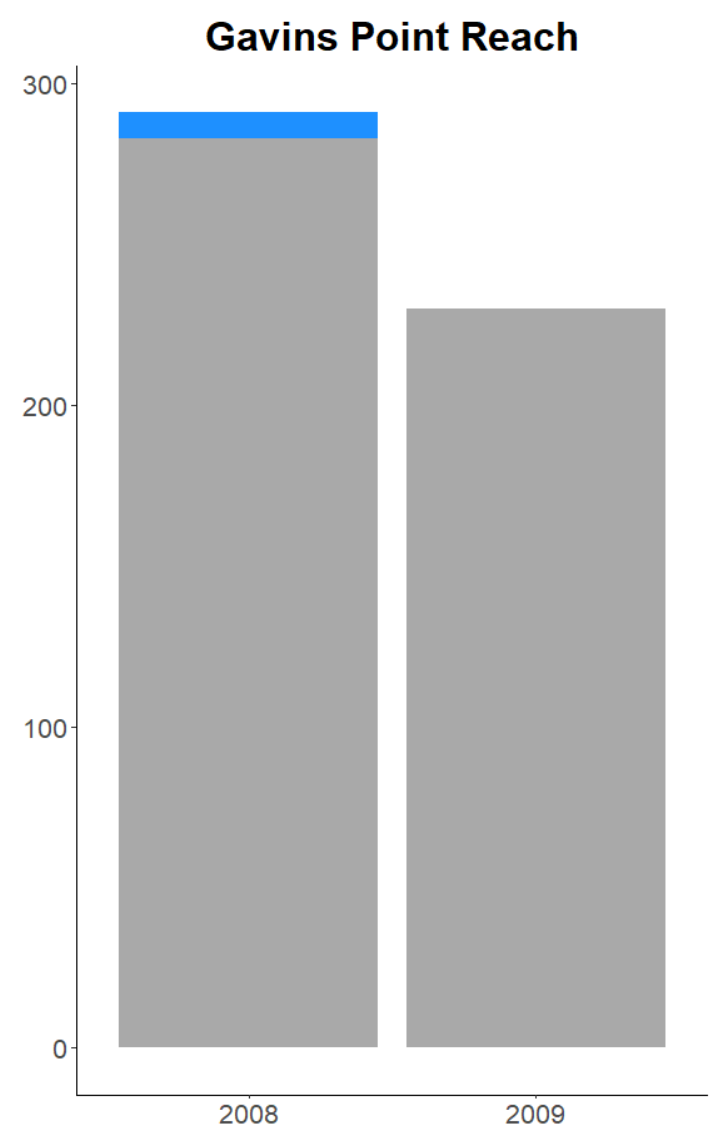

Figure A6. Number of least tern chicks raised on sandbars/segments in the presence of breeding least terns and/or piping plovers on the a) Garrison River Reach (2007, 2012-2016), b) Lake Sakakawea (2007-2008, 2012-2016), c) Gavins Point Reach (2008-2009). Note the y-axis scale changes has breeding abundances differ among study areas. 